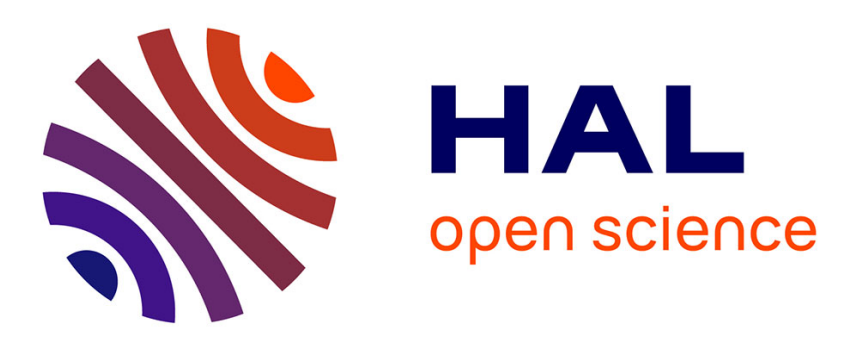

\title{
The Beneficial Effect of Mycorrhizae on N Utilization by the Host-Plant: Myth or Reality?
}

\author{
Anthony Gobert, Claude C. Plassard
}

\section{To cite this version:}

Anthony Gobert, Claude C. Plassard. The Beneficial Effect of Mycorrhizae on N Utilization by the Host-Plant: Myth or Reality?. Mycorrhiza: State of the Art, Genetics and Molecular Biology, EcoFunction, Biotechnology, Eco-Physiology, Structure and Systematics, 3ème éd., Springer Verlag, 2008, 10.1007/978-3-540-78826-3_11. hal-02814030

\section{HAL Id: hal-02814030 \\ https://hal.inrae.fr/hal-02814030}

Submitted on 6 Jun 2020

HAL is a multi-disciplinary open access archive for the deposit and dissemination of scientific research documents, whether they are published or not. The documents may come from teaching and research institutions in France or abroad, or from public or private research centers.
L'archive ouverte pluridisciplinaire HAL, est destinée au dépôt et à la diffusion de documents scientifiques de niveau recherche, publiés ou non, émanant des établissements d'enseignement et de recherche français ou étrangers, des laboratoires publics ou privés. 


\title{
The Beneficial Effect of Mycorrhizae on N Utilization by the Host-Plant: Myth or Reality?
}

\author{
Anthony Gobert, Claude Plassard(
}

\section{Introduction}

Nitrogen represents the major element in plants. This element is present in most of the basic constituents: purines, pyrimidines, and amino acids, and is important for the autotrophic capacity of the plants, being part of the light harvesting molecules, e.g., chlorophyll. De facto, $\mathrm{N}$ deficiency in plants leads rapidly to chlorosis and stunted growth. Plants being sessile organisms, they are completely dependent on the $\mathrm{N}$ availability in the soil solution for their growth and productivity.

In soil, a harsh competition exists for $\mathrm{N}$ acquisition between the microorganisms (mainly bacteria and fungi) and the plants. However, plant species have developed various strategies of $\mathrm{N}$ acquisition. These strategies are including microorganism partners into a symbiotic association. First, legumes are associated with bacteria to assimilate aerial N. A second form of mutualism is the association between plants and mycorrhizal fungi. The fungus and the plant are associated underground forming a close bound between the hyphae and the root cells, the so-called mycorrhizal root.

These mycorrhizal roots are characterized by the presence of an extensive network of mycelium developing out of the root and exploring the soil. Therefore, the fungal partner considerably increases the volume of soil that is exploited compared to the nonmycorrhizal root system (Rousseau et al. 19994). The mycelium also develops between the root cells inside the root cortex. All mineral and nutrient exchanges between the host cell (carbohydrate release) and the fungal cells (phosphorus and nitrogen release) are thought to take place in this fungal-plant interface (Smith and Read 1997). Melin and Nilsson (1952) were the first to demonstrate the $\mathrm{N}$ uptake by the extra radical mycelium and its transfer to the host plant. Since this pioneering study, a considerable amount of work has been devoted to the capacities of mycorrhizal symbiosis to modify the access to the various $\mathrm{N}$-forms from the soil, including the uptake and assimilation of $\mathrm{N}$ by the partners. The main purpose of

Claude Plassard

INRA-SupAgro, UMR 1222 Biogéochimie du Sol et de la Rhizosphère, 2, Place Viala, 34060 Montpellier Cedex 1, France

e-mail: plassard@ supagro.inra.fr 
this chapter is to summarize the present knowledge about the role of three main types of mycorrhizal associations made by ericoid, ectomycorrhizal and arbuscular mycorrhizal fungi in the nitrogen nutrition of the host plant. The first section reviews the capacities of these mycorrhizal fungi to influence the $\mathrm{N}$ cycle and data regarding the quantification of the $\mathrm{N}$ sources in the soil as depending on the ecosystem type. The second section presents the data dealing with the differential capacities of the host-plant and their fungal partners to take up and assimilate the different $\mathrm{N}$ sources (organic or mineral). The recent advances gained by molecular studies are detailed. In the third section, labeling experiments and molecular studies that have been carried out so far to highlight $\mathrm{N}$ transfer from the fungal cells to the host cells are described. Finally, data enabling us to assess the importance of $\mathrm{N}$ transfer in the $\mathrm{N}$ budget of the mycorrhizal plants in "real life" are considered.

\section{Dynamics of $\mathbf{N}$ in Terrestrial Environment and Availability of $\mathbf{N}$ in Soils}

\subsection{The N Cycle from a Mycorrhizal Point of View}

In most soils, insoluble organic $\mathrm{N}$ constitutes the dominant form of $\mathrm{N}$ present (Attiwill and Adams 1993). This $\mathrm{N}$ pool is available to plants only after processing into smaller soluble compounds by enzyme cleavage (Jones et al. 2005) that is one of the first steps of the $\mathrm{N}$ cycle. These $\mathrm{N}$-containing macromolecules are insoluble and are often protected or coprecipitated with other organic molecules such as lignins, polyphenols and tannins. Thus, these organic molecules have to be degraded by enzymes such as lignases and polyphenol oxidases before that organically-bound $\mathrm{N}$ becomes available and can be cleaved by proteases. Lignin can be degraded mainly by "white rot fungi" that are able to produce lignin (LiP) and manganese $(\mathrm{MnP})$ peroxidases. These enzymes digest the aromatic structures of the polymer (Read and Perez-Moreno 2003). The presence of these enzymes has been searched in mycorrhizal fungi that can be cultured in vitro that are ericoid (ERM) and ectomycorrhizal (EM) fungi. Indeed, the capability to produce such enzymes would be of particular relevance in the habitat of these fungi. Ericoid fungi are found in heathland ecosystems characterized by acidic raw humus soils containing high amounts of lignin and polyphenolic compounds. Depending on the climate, EM fungi are also found in boreal forest soils which are characterised by high levels of the same organic molecules. However, so far, studies carried out on the most investigated ERM species, Hymenosciphus ericae (Bending and Read 1996, 1997; Burke and Cairney 1998), have failed to find evidence for the production of LiP or MnP. The ability of this fungal species to grow on the aromatic constituents of lignin demonstrated by respirometric methods (Haselwandter et al. 1990) may be attributed to the release of hydrogen peroxide (Bending and Read 1997) and hydroxyl radicals (Burke and Cairney 1998) that can contribute to lignin degradation, 
like the "brown rot" fungi (Read and Perez-Moreno 2003). Similarly, the data available on the ability of EM fungi to degrade lignin comes from gene expression studies of MnP (Chambers et al. 1999; Chen et al. 2001) or LiP (Chen et al. 2001) and not from enzyme activity measurements. Contrary to lignin digestion, the extracellular excretion of enzymes such as polyphenol oxidase, peroxidase and laccase that are capable of degrading soil phenolic acids and tannins was clearly demonstrated for ERM and EM fungi (Read and Perez-Moreno 2003; Courty et al. 2005). These observations indicate that those fungal species could play a significant role in organic molecules degradation found in heathland and forest soils. This degradation is a pre-requisite to "unmask" organic N compounds before their cleavage by specialised enzymes, the proteases. In contrast to ERM and ECM fungi, it is considered that the arbuscular mycorrhizal fungi (AMF) have no saprotrophic capabilities to enable $\mathrm{N}$ mineralisation from organic matter (Read and Perez-Moreno 2003). So far, there is a single report demonstrating enhanced decomposition of organic necromass by AMF (Hodge et al. 2001). In this experiment, external hyphae of AMF extending from colonized roots were supplied with dual ${ }^{15} \mathrm{~N} /{ }^{13} \mathrm{C}$ labeled grass leaves in a fungal compartment. AM hyphae were shown to facilitate enhancement of $\mathrm{N}$ capture from the litter, the $\mathrm{N}$ gain in the plants being linearly related to hyphal density in the organic matter. However, this study was not carried out in monoxenic conditions and one cannot exclude that the AM hyphae could act as facilitators, rather than directly, of decomposition and nutrient release. Indeed, AM hyphae are known to increase allocation of carbon from the host-plant to the soil system. This carbon supply could greatly enhance the activity of microbial generalists in the AMF compartment, those microbes that may be involved in decomposition and nutrient release (Read and Perez-Moreno 2003).

The first step of N-containing organic matter digestion is the cleavage of proteins by the proteases. Bending and Read (1996) demonstrated that H. ericae was able to acquire $\mathrm{N}$ from complex $\mathrm{N}$ sources through the expression of extracellular acid protease activities. It is interesting to note that this fungal species is able to grow on a range of $\mathrm{N}$ compounds such as chitin, supplied either as crustacean chitin (Leake and Read 1990) or as purified fungal cell wall of $H$. ericae itself (Kerley and Read 1997). Extracellular protease activities have also been measured in ECM fungi (Chalot and Brun 1998; Smith and Read 1997), but at a lower level than those measured in ERM fungi. In addition, availability of $\mathrm{N}$ sources and /or climate conditions appears to select ECM fungal species regarding their proteolytic capacities. Northern boreal forests with raw humus soils have ECM fungal communities more diverse and more able to develop on proteins supplied as the sole source of $\mathrm{N}$ and $\mathrm{C}$ than those isolated from southerly locations where $\mathrm{N}$ enrichment occurs (Taylor et al. 2000). Observations made by Tibbett et al. $(1998,1999)$ on different strains of the ECM fungus Hebeloma - greatest proteolytic potential for strains from cold environments and very low thermal optimum for activity of protease $\left(0-6^{\circ} \mathrm{C}\right)-$ indicated also that selection may favor "protein fungi" in arctic and boreal environments. After protein hydrolysis, the subsequent step of the $\mathrm{N}$ cycle will be the release of $\mathrm{NH}_{4}^{+}$in the environment from amino acids by desaminases. To our knowledge, there is only one study reporting the production of free $\mathrm{NH}_{4}^{+}$into the 
medium by an ECM fungus, Hebeloma crustuliniforme (Quoreshi et al. 1995). This net release of $\mathrm{NH}_{4}^{+}$occurred only when the fungus was grown without glucose in the medium. The same observation was made on another Hebeloma species, $H$. cylindrosporum (Plassard, unpublished data). However, more work is needed to quantify the importance of this ammonium release in situ.

\subsection{Quantification of the N Sources in the Soil}

$\mathrm{N}$ sources that can be used by plants, their fungal symbionts and more generally microorganisms are either mineral $\left(\mathrm{NH}_{4}^{+}\right.$and $\left.\mathrm{NO}_{3}^{-}\right)$or organic (mainly small peptides and amino acids). Many studies have been undertaken to measure the concentrations of these different $\mathrm{N}$ sources in soil. Examples of mean values measured in the soil solution extracted by the drainage/centrifugation method (Christou et al. 2006; Jones et al. 2004, 2006), Rhizon tension lysimeters (Andersson and Berggren 2005) or water incubation (Gessler et al. 1998) are given in Table 1. Although not strictly identical, one can consider that these methods approximate the minimal concentrations of nutrients present in the soil solution. Seasonal variations clearly affect the absolute values of $\mathrm{N}$ concentrations (see the Mediterranean vineyard) and boreal climatic conditions clearly decrease $\mathrm{N}$ concentration in the solution (Table 1). Finally, under temperate climates, the most abundant $\mathrm{N}$ forms are $\mathrm{NO}_{3}^{-}$and dissolved organic nitrogen (DON), regarding their concentrations as well as their proportions relative to the total $\mathrm{N}$ (Table 1). Surprisingly, $\mathrm{NO}_{3}^{-}$concentrations assayed in soil sampled in coniferous species (Picea sitchensis and Larix decidua) are of the same order of magnitude than those assayed in a Mediterranean vineyard. These data indicate that nitrification should be active in these forest soil conditions. However, as underlined by Jones et al. (2005), such large pools of $\mathrm{NO}_{3}{ }^{-}$and DON may occur simply because they contain $\mathrm{N}$ forms that are not used easily by plants or microorganisms. If the same argument is held for $\mathrm{NH}_{4}^{+}$and free amino acids whose concentrations and proportions to total $\mathrm{N}$ are always very low, these two $\mathrm{N}$ pools should be used in priority for uptake. Nevertheless, one have to keep in mind that ammonium and free amino acids can be readily adsorbed onto the solid constituents of soil (Barber 1995; Jones and Hodge 1999; Qualls and Richardson 2003; Vieublé Gonod et al. 2006), thus minimizing their concentrations in soil solution. However, more important than the actual size of the relative $\mathrm{N}$ pools in soils is the rate of flux through these pools (Jones et al. 2005). Indeed, using ${ }^{15} \mathrm{~N}$-pool-dilution techniques in short-term experiments, it has been shown that the inorganic $\mathrm{N}$ pools are subjected to high turnover due to microbial use (Kaye and Hart 1997; Grenon et al. 2005). This is also the case for free amino acids, with half-life expectancy typically ranging from 1 to $12 \mathrm{~h}$, indicating an extremely fast turnover rate (Jones 1999; Jones and Kielland 2002; Jones et al. 2004).

The other factor that has to be taken into account is the high spatio-temporal variability of mineralization processes between the different soil layers, as illustrated in Table 2. In the forest soils studied, the potential mineralization rates of 


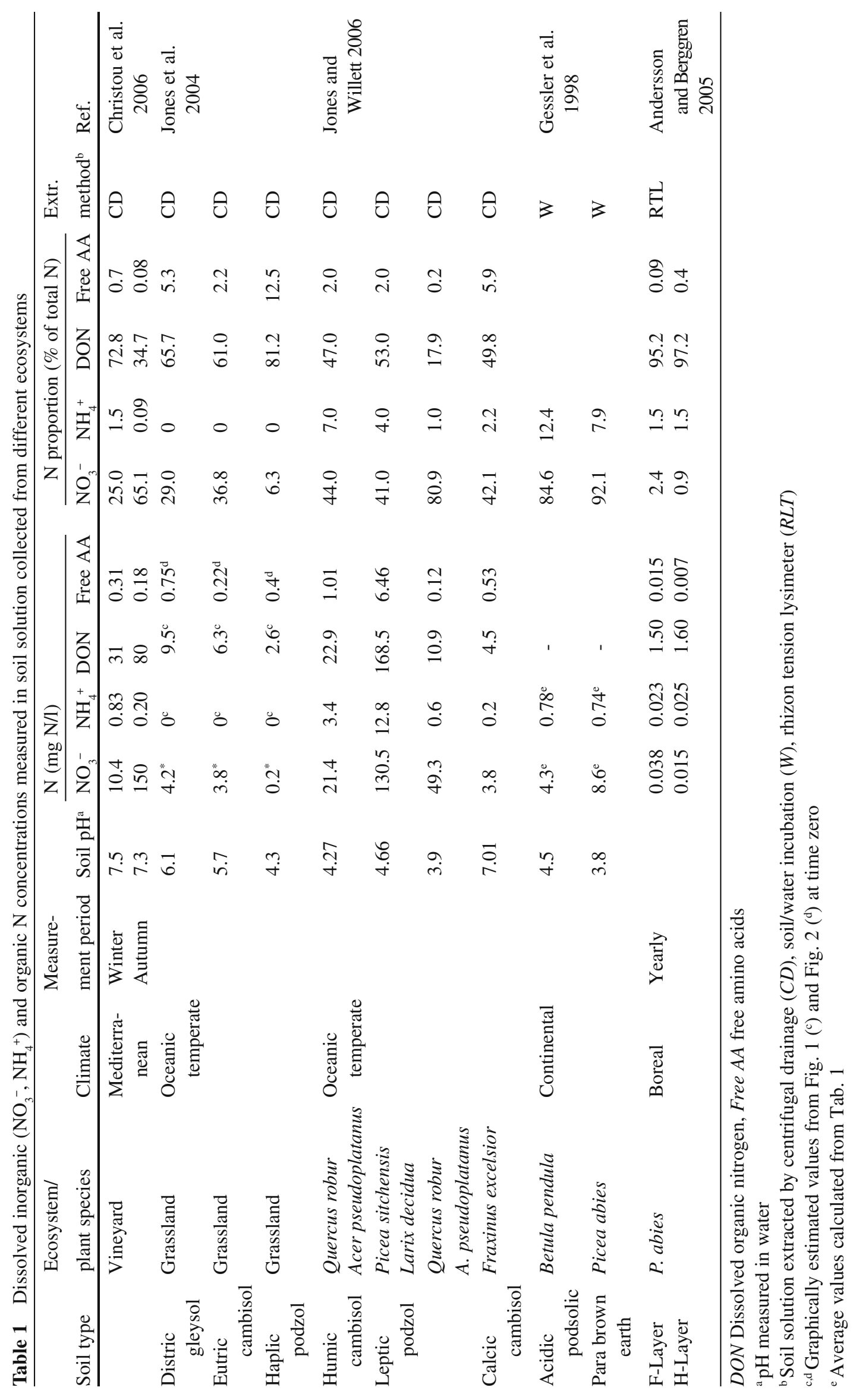


Table 2 Potential rates of $\mathrm{NH}_{4}^{+}$and $\mathrm{NO}_{3}{ }^{-}$production in organic layers $(O L, O F, O H)$ and upper mineral soil (UMS) sampled in pure Fagus sylvatica and mixed F. sylvatica and Carpinus betulus deciduous temperate forests. Rates of mineral $\mathrm{N}$ production were measured after laboratory incubation carried out at $28^{\circ} \mathrm{C}$ for 28 days (data calculated from Aubert et al. 2005)

\begin{tabular}{lcccc}
\hline & \multicolumn{3}{c}{ Production rate $\left(\mu \mathrm{g} \mathrm{N} \mathrm{g}^{-1}\right.$ soil dw day $\left.{ }^{-1}\right)$} \\
\cline { 2 - 3 } \cline { 2 - 3 } Layer & \multicolumn{2}{c}{$\mathrm{NH}_{4}{ }^{+}$in } & & $\mathrm{NO}_{3}^{-}$in \\
\cline { 2 - 3 } \cline { 5 - 6 } OL & 750 & 200 & Pure stand & Mixed stand \\
OF+OH & 1250 & 400 & 9 & 3 \\
UMS & 60 & 30 & 27 & 9 \\
OL/UMS & 12.5 & 6.7 & 1.2 & 0.6 \\
OF+OH/UMS & 21 & 13 & 7.5 & 5.0 \\
\hline
\end{tabular}

$\mathrm{NH}_{4}^{+}$production are much faster in organic layers than in upper mineral soil and the same trend is observed for nitrification (Aubert et al. 2005) (Table 2). Generally speaking, the new $\mathrm{N}$ sources produced from hydrolysis of complex $\mathrm{N}$ sources are subjected to competition between several processes, that can be physical such as adsorption on solid phase and/or biological such as plant or symbiotic fungal uptake or soil microbial utilisation. Therefore, plants and their fungal symbionts may be supplied with pools of $\mathrm{N}$ sources of extreme variable sizes, with a high competition for $\mathrm{N}$ capture between the numerous organisms living together and the soil itself.

\section{Absorption and Assimilation of Nitrogen by the Partners of the Mycorrhizal Symbiosis}

\subsection{Organic N Forms: Peptides and Amino Acids}

The first forms of $\mathrm{N}$ that can be used by plants and their associated fungi are organic $\mathrm{N}$ compounds such as small peptides and amino acids. Due to its interest to bypass the $\mathrm{N}$ mineralization process, an appreciable research effort has been devoted to the capacities of plants to take up organic N. Pioneering work was made by Read and collaborators (Smith and Read 1997) by studying the growth and N accumulation in young seedlings of Ericaceae (Stribley and Read 1980) and Betula pendula (Abuzinadah and Read 1989) supplied with different organic N sources. Their results showed the restricted capabilities of the nonmycorrhizal host plants to use single amino acids as well as oligopeptides (Abuzinadah and Read 1989). The same conclusions were drawn from experiments carried out using L-glutamate supplied to Pinus pinaster (Plassard et al. 2000) or various amino acids supplied to Eucalyptus grandis and E. maculata (Turnbull et al. 1996), although the two Eucalypts were able to use L-glutamine as $\mathrm{N}$ source. The same results were obtained when complex substrates such as bovine serum albumine (BSA) or gliadin were supplied to nonmycorrhizal plants of Vaccinium macrocarpon (Bajwa et al. 
1985) or Pinus contorta (Finlay et al. 1992), indicating that, at least the few plant species studied exhibited a rather poor capacity to use such $\mathrm{N}$ organic sources when nonmycorrhizal. Clearly, these host-plants were able to utilize organic $\mathrm{N}$ and/or complex $\mathrm{N}$ sources when associated with mycorrhizal fungi (Smith and Read 1997). Indeed, numerous studies indicated that, in contrast to the host plant, amino acids can be an important source of $\mathrm{N}$ for fungal growth as demonstrated for several ectomycorrhizal fungi (Scheromm et al. 1990; Finlay et al. 1992; Quoreshi et al. 1995; Plassard et al. 2000; Wipf et al. 2002; Guidot et al. 2005) and the ericoid fungus, Hymenoscyphus ericae, although large intraspecific variation was observed for this species (Cairney et al. 2000; Grelet et al. 2005).

Given the potential importance of organic N use in boreal conditions (Näsholm et al. 1998), this question has been reviewed recently (e.g., Lipson and Näsholm 2001; Näsholm and Persson 2001). According to these reviews, substantial effort has been made in two directions: (1) the study of molecular properties of amino acid transporters, and (2) the measurement of kinetic parameters in various organisms. Although most of the properties of amino acid transport systems have been elucidated from studies of yeast (Saccharomyces cerevisiae), numerous studies have confirmed the presence of genes encoding similar transporters in plants (i.e., Fischer et al. 1998). A wide range of transporter genes has been identified so far in Arabidopsis thaliana that are expressed in roots of the model plant (Näsholm and Persson 2001). These genes encode low affinity general amino acid transporter, high affinity neutral/acid amino acid transporter, proline transporter, high affinity transporter of basic amino acids, lysine/histine transporter and di- and tripeptide transporter, suggesting that the roots can take up a wide range of organic $\mathrm{N}$ sources. Molecular studies have been carried out in two ectomycorrhizal species, Amanita muscaria and Hebeloma cylindrosporum (Table 3). These studies identified a general amino acid acid transporter (AmAAP1) with high affinity for basic amino acids and somewhat lower affinity for neutral and acidic amino acids in A. muscaria (Nehls et al. 1999).

In $H$. cylindrosporum, several transporters have been recently identified: HcGAP1, a general amino acid transporter (Wipf et al. 2002); HcPTR2A and HcPTR2B, two dipeptide transporters (Bendjia et al. 2006); and HcOPT1, an oligopeptide transporter (Müller et al. 2007) (Table 3). The other important set of data deals with the measurement of amino acid uptake rates. As summarized by Lipson and Näsholm (2001), various organisms are able to take up amino acids, in various ecosystems, suggesting that organic $\mathrm{N}$ could be a suitable $\mathrm{N}$ source for host-plant growth besides mineral N. For example, amino acid absorption was demonstrated for several species of ericoid endomycorrhizal (Sokolovski et al. 2002; Midgley et al. 2004) and ectomycorrhizal fungi (Boukcim and Plassard 2003; Chalot and Brun 1998; Wallenda and Read 1999). Recently, the capacity of uptake and transport of two amino acids (L-Gly and L-Glu) by the external hyphae of Glomus mossae associated with wheat was shown (Hawkins et al. 2000). In addition to laboratory experiments, recent studies were carried out in the field to assess the actual use of organic $\mathrm{N}$ in situ, either in boreal (Persson et al. 2003), oceanic (Bennett and Prescott 2004) or Mediterranean (Warren 2006) conditions. In boreal conditions, 
Table $3 \mathrm{~N}$ uptake and $\mathrm{N}$ metabolism related genes of mycorrhizal fungi which have been cloned and characterized or whose expression has been determined. Corresponding accession numbers (NCBI, http://www.ncbi.nlm.nih.gov/) are given in parentheses

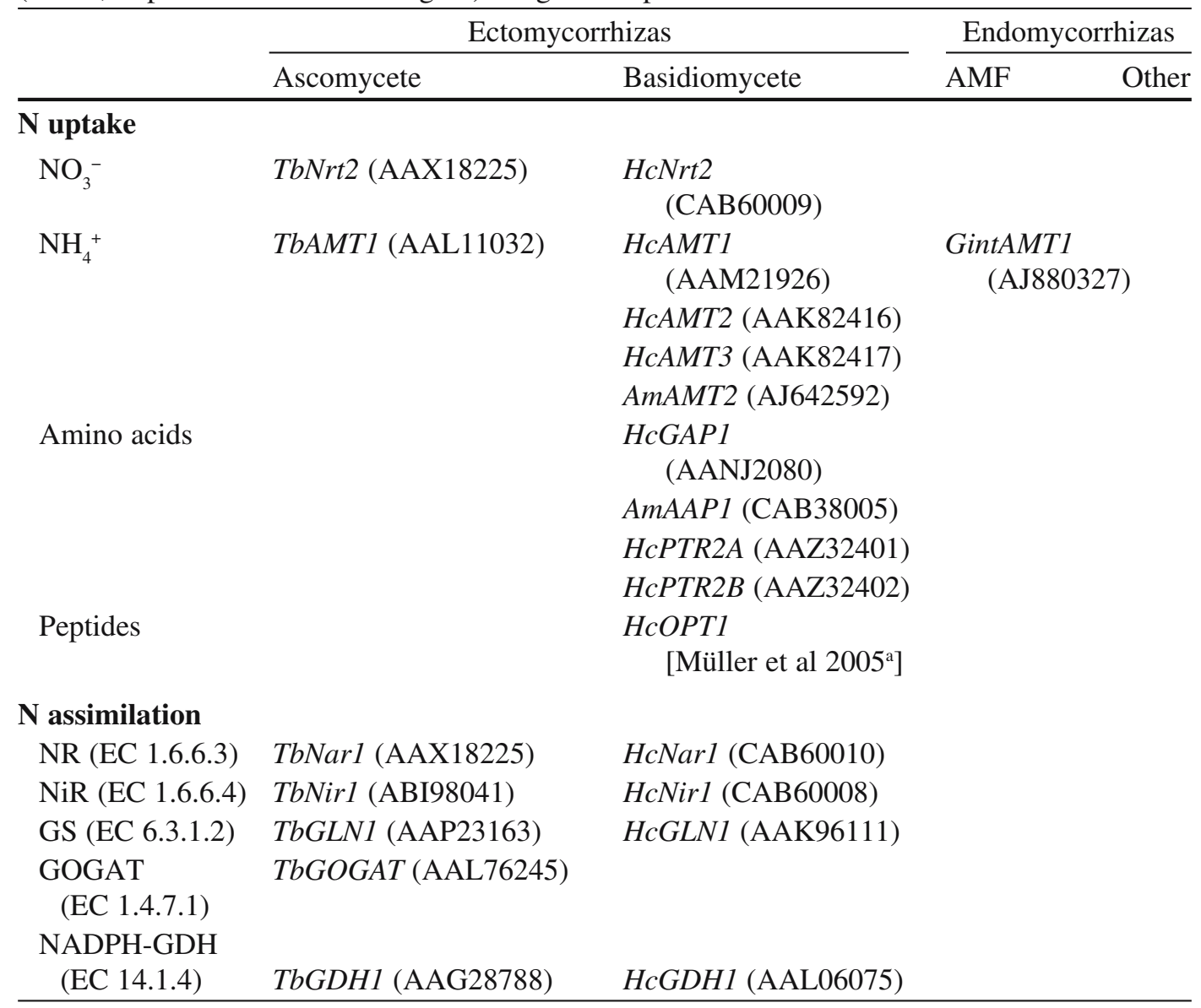

a The accession number is not available, instead the reference is given

mineral or organic $\mathrm{N}$ sources (arginine, glycine and peptides) labelled with ${ }^{15} \mathrm{~N}$ and ${ }^{13} \mathrm{C}$ were injected into the soil and ${ }^{15} \mathrm{~N}$ accumulation was measured in roots of Deschampsia flexuosa, Picea abies and Vaccinium myrtillus after short (6-h) or long-term (65-day) incubation (Persson et al. 2003). Significant differences were found between $\mathrm{N}$ sources and plant species only after 65 days of labeling. P. abies and $V$. myrtillus accumulated more ${ }^{15} \mathrm{~N}$ from glycine and peptides than the grass $D$. flexuosa, although arginine was poorly accumulated in the three species. This may be due to the very low mobility of this strongly cationic amino acid, and its large immobilization in the soil (Persson et al. 2003). Use of organic and mineral $\mathrm{N}$ by red cedar (Thuya plicata), hemlock (Tsuga heterophylla) and salal (Gaultheria shallon) under oceanic climate was assessed by measuring ${ }^{15} \mathrm{~N}$ accumulation in the whole plant after injection of mineral $\mathrm{N}$ and organic $\mathrm{N}$ (L-glutamic acid, protein and protein-tannin) up to 20 days after injection (Bennett and Prescott 2004). Contrary to the results of Persson et al. (2003), organic N was accessed to a modest degree compared to mineral $\mathrm{N}$ sources by all three species, and the ericacous species Salal did not have a greater capacity to utilize protein and protein-tannin-N. Attached roots of six Eucalyptus species incubated simultaneously in situ with 
dualy labeled ${ }^{13} \mathrm{C}$ - and ${ }^{15} \mathrm{~N}$-glycine, ${ }^{15} \mathrm{NH}_{4}^{+}$and ${ }^{15} \mathrm{NO}_{3}^{-}$were shown to accumulate glycine at lower rates than ammonium $\left(3.4 \pm 0.2\right.$ and $6.3 \pm 0.4 \mu \mathrm{mol} \mathrm{g}^{-1} \mathrm{~h}^{-1}$, respectively) and higher rates than nitrate $(0.63 \pm 0.07)$, suggesting that organic $\mathrm{N}$ uptake might be of considerable importance in the field (Wallenda and Read 1999). However, it should be noticed that ${ }^{15} \mathrm{~N}$ accumulation in the root from organic $\mathrm{N}$ supply does not mean that it is a good $\mathrm{N}$ source. As underlined by Jones et al. (2005), root cell walls have negative charges that can accumulate positive charged compounds such as ammonium and amino acids by adsorption. Also, it was shown that Pinus pinaster plants supplied with ${ }^{15} \mathrm{~N}$-labelled glutamate or ${ }^{15} \mathrm{NH}_{4}^{+}$for $24 \mathrm{~h}$ accumulated ${ }^{15} \mathrm{~N}$ from two $\mathrm{N}$ sources at the same rates in their roots, although Pinus pinaster plants grew very poorly with L-glutamate without mycorrhizal association (Plassard et al. 2000). This poor growth was due to a very low flux of ${ }^{15} \mathrm{~N}$ from Lglutamate towards the shoots, contrary to ammonium. Thus, to assess accurately the actual utilization of organic $\mathrm{N}$ by plants, it is necessary to measure accumulation in the roots and in the shoots.

\subsection{Mineral N Forms: Ammonium and Nitrate}

It is well documented that ectomycorrhizal fungi have a preference for ammonium over nitrate (Rangel-Castro et al. 2002; Guidot et al. 2005), but it is not unusual to find ectomycorrhizal fungi being able to grow better with nitrate over ammonium (Scheromm et al. 1990; Montanini et al. 2002). In contrast, the ectomycorrhizal fungus Amanita muscaria is not able to grow with nitrate as the sole source of N. The preferential $\mathrm{N}$ source for optimum growth is not only dependent on the species but on the strains studied (Scheromm et al. 1990; Guidot et al. 2005). The same observation was reported for several strains of Hymenoscyphus ericae (Cairney et al. 2000; Grelet et al. 2005). We can assume that the strains are adapted to (or have been selected through) the nitrogen availability in the soil from which they have been extracted. These strains must therefore have different ability to take up $\mathrm{N}$.

Early studies conducted on excised and intact ectomycorrhizal root systems evidenced the enhanced ammonium uptake capacity of mycorrhizal plants as compared to their uninfected counterparts (Genetet et al. 1984; Rousseau et al. 1994). An enhanced uptake of nitrate from ectomycorrhizal short roots was also found in the association Rhizopogon roseolus and Pinus pinaster (Gobert and Plassard 2002), although this positive effect was strongly fungal-species dependent (Plassard et al. 2000). Interestingly, the regulation of nitrate uptake seems to be different in the host-plant and the ectomycorrhizal fungus, as shown in the association Rhizopogon roseolus and Pinus pinaster (Gobert and Plassard 2002). The fungal nitrate uptake is maximal with or without nitrate in the solution, contrary to the nonmycorrhizal host plant that needs several days of incubation in nitrate solution to reach its maximal level. The kinetics of nitrate uptake into ectomycorrhizal roots as a function of nitrate availability are identical to those established in the fungus alone, suggesting that anion uptake into fungal cells dominate that of root cells in the ectomycorrhizal roots. Such a pattern of uptake could give a broader access to 
the ectomycorrhizal plant at fluctuating nitrate availability in the field (Gobert and Plassard 2002).

In addition to the physiological data accumulated on $\mathrm{N}$ uptake by the partners and their association, a lot of effort has been devoted to molecular studies in the last decade. The cloning and functional characterization of genes have broadened the knowledge on the pathway of $\mathrm{N}$-uptake and assimilation by mycorrhizal fungi (Table 3). Studies on a few species of ectomycorrhizal fungi start to give a good picture of the molecular actors contributing to the $\mathrm{N}$ uptake and assimilation, but very few data are available for the endomycorrhizal fungi and this becomes rarer for the other type of mycorrhizal fungi. Amanita muscaria (Am), Hebeloma cylindrosporum ( $\mathrm{Hc}$ ) and Tuber borchii $(\mathrm{Tb})$ are the leading ectomycorrhizal fungi concerning the cloning and the expression patterns of the genes coding the proteins involved in inorganic and organic $\mathrm{N}$ uptake. Whereas $H c$ and $A m$ are phylogenetically close (Basidiomycetes, Agaricales), $\mathrm{Tb}$ is far apart (Ascomycetes). The strains studied are coming from various types of soils. The Tuber strain comes from a calcareous soil poor in organic matter (good mineralization), the Hebeloma strain comes from a sandy soil (poor mineralization) and the Amanita strain comes from a temperate forest (poor mineralization). $\mathrm{Hc}$ and $\mathrm{Tb}$ possess a high affinity $\mathrm{NO}_{3}^{-}$ transporter Nrt2 (Jargeat et al. 2003; Montanini et al. 2006). Gobert and Plassard (2002) have shown that the ectomycorrhizal fungus Rhizopogon roseolus (Basidiomycetes) displays only one kinetics of $\mathrm{NO}_{3}{ }^{-}$uptake. The Nrt2 transporter identified so far might therefore be the only high affinity transporter in these fungal species in contrast to the plants that have several transporters. Genes encoding Nitrate Reductase (EC 1.6.6.3) and Nitrite Reductase (EC 1.6.6.4) have also been cloned from $\mathrm{Hc}$ and $\mathrm{Tb}$ (Table 3). All three genes are clustered in both fungi. $\mathrm{Tb} /$ $\mathrm{HcNrt} 2$ and $\mathrm{Tb} / \mathrm{HcNirl}$ are upregulated in presence of $\mathrm{NO}_{3}{ }^{-}$and even under $\mathrm{N}$ starvation whereas $\mathrm{TbNr} 1$ is only upregulated in presence of $\mathrm{NO}_{3}^{-}$(Jargeat et al. 2000; Guescini et al. 2007). All three genes are under ammonium repression in $H c$, but it seems that $\mathrm{TbNrl}$ is not regulated in the same way. $\mathrm{TbNr} 1$, TbNrt2 are strongly expressed in the Hartig net and mantle but weakly expressed into the free-living mycelia (Guescini et al. 2003; Montanini et al. 2006).

Like plants, AMT transporters are responsible for the $\mathrm{NH}_{4}^{+}$uptake in fungi. Three genes encoding transporters have been cloned from Hc (Javelle et al. 2001, 2003) and a single one from Tb (Montanini et al. 2002), Am (Willmann et al. 2007) and Glomus intraradices (Lopez-Pedrosa et al. 2006). HcAmt3 is a low affinity ammonium transporter but HcAmt1 and HcAmt2 are high affinity ammonium transporters/sensors. $\mathrm{HcAMTl}$ is expressed under $\mathrm{N}$ deficiency and $\mathrm{NO}_{3}^{-}$feeding and repressed by glutamine. HcAMT3 is highly expressed but not highly regulated. In Tuber, TbAMT1 seems to be only upregulated under $\mathrm{N}$ deficiency. The upregulation of $T b A M T 1$ after transfer of $T b$ in $-\mathrm{N}$ solution is slow (matter of days) but its downregulation after $\mathrm{N}$ resupplementation is fast (matter of hours). $\mathrm{NH}_{4}^{+}, \mathrm{NO}_{3}{ }^{-}$and glutamine downregulate the transporter (certainly via the glutamine pool as in $\mathrm{Hc}$ ) but proline has no effect ( $T b A M T 1$ remains upregulated) showing that proline is a poor $\mathrm{N}$ source as in yeast and $H c$. In the case of Amanita, the gene coding for a high affinity ammonium transporter, AmAMT2, is upregulated in $-\mathrm{N}$ and nitrate solution 
as for HcAMT1. The Amanita strain studied is not able to use nitrate. AmAmt1 expression decreases with increasing concentrations of ammonium in the medium with a basal expression reached at $500 \mu \mathrm{M} \mathrm{NH}_{4}{ }^{+}$as is the case for TbAMT1. The expression is further reduced during the formation of ectomycorrhizal roots with the same level of expression in the mantle and the Hartig net. On the contrary, the expression was high in the extraradical mycelium. The last $A M T$ member cloned from mycorrhizal fungi is GintAMT1 from Glomus intraradices (Lopez-Pedrosa et al. 2006). It codes for a high affinity ammonium transporter upregulated in low $\mathrm{N}$ avaibility and nitrate solution. The downregulation of GintAMT1 is correlated with increasing concentration of $\mathrm{NH}_{4}^{+}$. The transcription of the AMT transporters from mycorrhizal fungi is regulated by the $\mathrm{N}$ status of the plant (via the level of glutamine). It is interesting to see that two fungi whose growth is slow on nitrate produce high level of expression of the $A M T$ in nitrate solution but the picture is not clear for Glomus and Tuber. Indeed, these nitrate users seem to possess different regulation. GintAMT1 expression is regulated as the previous fungi mentioned and TbAMT1 expression is downregulated under nitrate. However, the Glomus study does not include a starvation step contrary to the other ectomycorrhizal fungi.

$\mathrm{NH}_{4}^{+}$produced by nitrate reduction or taken up from the external medium has to be incorporated in $\mathrm{C}$ skeleton. This can occur through two ways involving glutamine synthase and glutamine oxoglutarate amino-transferase (GS/GOGAT pathway) or glutamate deshydrogenase and glutamine synthase (GDH/GS pathway). Numerous studies involving these enzymes have been done in different fungi (Bedell et al. 1994; Martin et al. 1994; Javelle et al. 2003; Morel et al. 2006). The GDH/GS pathway seems to dominate in mycorrhizal fungi but the GS/GOGAT dominates in plants. However, depending on the fungal species, GDH activities and polypeptides can be detected or not in ectomycorrhizal roots (Botton and Dell 1994). Interestingly, the fungal aspartate aminotransferase activity was not detected in ectomycorrhizae whereas the activity of root isoenzymes was stimulated (Botton and Dell 1994). Taken all together, these data indicate that expression of enzymes involved in primary assimilation of ammonium in fungal and plant compartments is highly regulated by the mycorrhizal status.

\section{Transfer of Nitrogen to the Host Plant}

\subsection{Direct Methods to Study the Transfer}

The demonstration of a net nitrogen transfer from the fungal cells to the root cells was first established by supplying mineral $\mathrm{N}$ sources labelled with ${ }^{15} \mathrm{~N}$ to the hyphae of an ectomycorrhizal fungus physically separated from the roots of pine seedlings by a barrier (Melin and Nilsson 1952). More recently, Finlay et al. (1988) showed also that the hyphae of four ectomycorrhizal species, Rhizopogon roseolus, 
Suillus bovinus, Paxillus involutus and Pisolithus tinctorius, associated with Pinus sylvestris seedlings, were able to take up, assimilate and translocate $\mathrm{N}$ from ${ }^{15} \mathrm{~N}$ labelled $\mathrm{NH}_{4}^{+}$. Labeling was measured in the free amino acid fraction extracted from mycelium (above the barrier), mycorrhizal tips, roots and needles. Whatever the fungal species, the greatest ${ }^{15} \mathrm{~N}$ abundancy was measured in the pools of alanine, glutamate + glutamine and aspartate + asparagine, in the mycelium and mycorrhizal tips. The same trend of ${ }^{15} \mathrm{~N}$ labelling was found in plant tissues, although the fungal species clearly affected the difference between ${ }^{15} \mathrm{~N}$ abundancy measured in fungal and plant compartment (Finlay et al. 1988). The same experimental system was then used by several workers (Finlay et al. 1989; Arnebrandt et al. 1993; Ek et al. 1996; Ek 1997), with different ${ }^{15} \mathrm{~N}$ sources and combinations of fungal species and host plant (Table 4). Another experimental system made of two PVC tubes (diameters of 10 and $15 \mathrm{~cm}$ ) forming a cylindrical inner (fungal) and a ring-shaped outer (plant) compartment was used by Brandes et al. (1998) and Jentschke et al. (2001) to grow the association Picea abies/Paxillus involutus (Table 4). The inner compartment was accessible only to the hyphae through a nylon mesh. In this system, both compartments were filled with pure sand and nutritive solutions were supplied separately to the plant and the fungus enabling controlled addition of nutrients. Also, the solutions draining from each compartment were collected separately, enabling the measurement of several parameters to follow mineral acquisition by the plant and the fungus. $\mathrm{N}$ transfer between plants connected together by the same mycelium was also studied, especially between a $\mathrm{N}_{2}$-fixing and a non- $\mathrm{N}_{2}$ fixing tree either using a microcosm (Arnebrandt et al. 1993) or a two-chambered pot made with a nylon mesh (He et al. 2004, 2005). As shown in Table 4, it was possible to measure ${ }^{15} \mathrm{~N}$ accumulation in the receiver plant in various experimental conditions. In microcosm studies, the labeling period was rather short (matter of days) and amounts of ${ }^{15} \mathrm{~N}$ translocated from $\mathrm{NH}_{4}^{+}$were greater than that translocated from $\mathrm{NO}_{3}^{-}$(Ek 1997; Finlay et al. 1989) although the two mineral sources were supplied at the same concentration. Also, more translocated ${ }^{15} \mathrm{~N}$ was retained in the roots when nitrate was supplied (Finlay et al. 1989).

When two receiver plants were connected with the same mycelium (Ek et al. 1996), the plant species receiving the largest amount of ${ }^{15} \mathrm{~N}$ also supplied most of the carbohydrates to the fungus, suggesting that the regulation of $\mathrm{N}$ and $\mathrm{C}$ exchanges between the plant and the fungus could be linked together. A more complex situation consisted of studying $\mathrm{N}$ exchanges between non-nitrogen- and nitrogen-fixing host plants (Arnebrandt et al. 1993). When ${ }^{15} \mathrm{~N}_{-} \mathrm{NH}_{4}{ }^{+}$was supplied to the mycelium of $P$. involutus connected to Pinus contorta and non-fixing Alnus glutinosa, ${ }^{15} \mathrm{~N}$ flux was clearly directed to Pinus contorta only. Surprisingly, ${ }^{15} \mathrm{~N}$ translocation to $A$. glutinosa was detectable when the host plant was nitrogen fixing (Table 4). When microcosms were exposed to ${ }^{15} \mathrm{~N}_{2}$ gas, interplant translocation of ${ }^{15} \mathrm{~N}$ was observed, amounting to $7 \%$ of the total ${ }^{15} \mathrm{~N}_{2}$ fixed (calculation based on Fig. 2 in Arnebrandt et al. 1993). This demonstration of a $\mathrm{N}$ transfer between a $\mathrm{N}_{2}$-fixing plant to a nonfixing plant is, to our knowledge, a unique one. The main limit of the studies carried out in microcosm is the duration of the labeling period that is generally short. This was overcome by using containers with two chambers, separating either the roots 


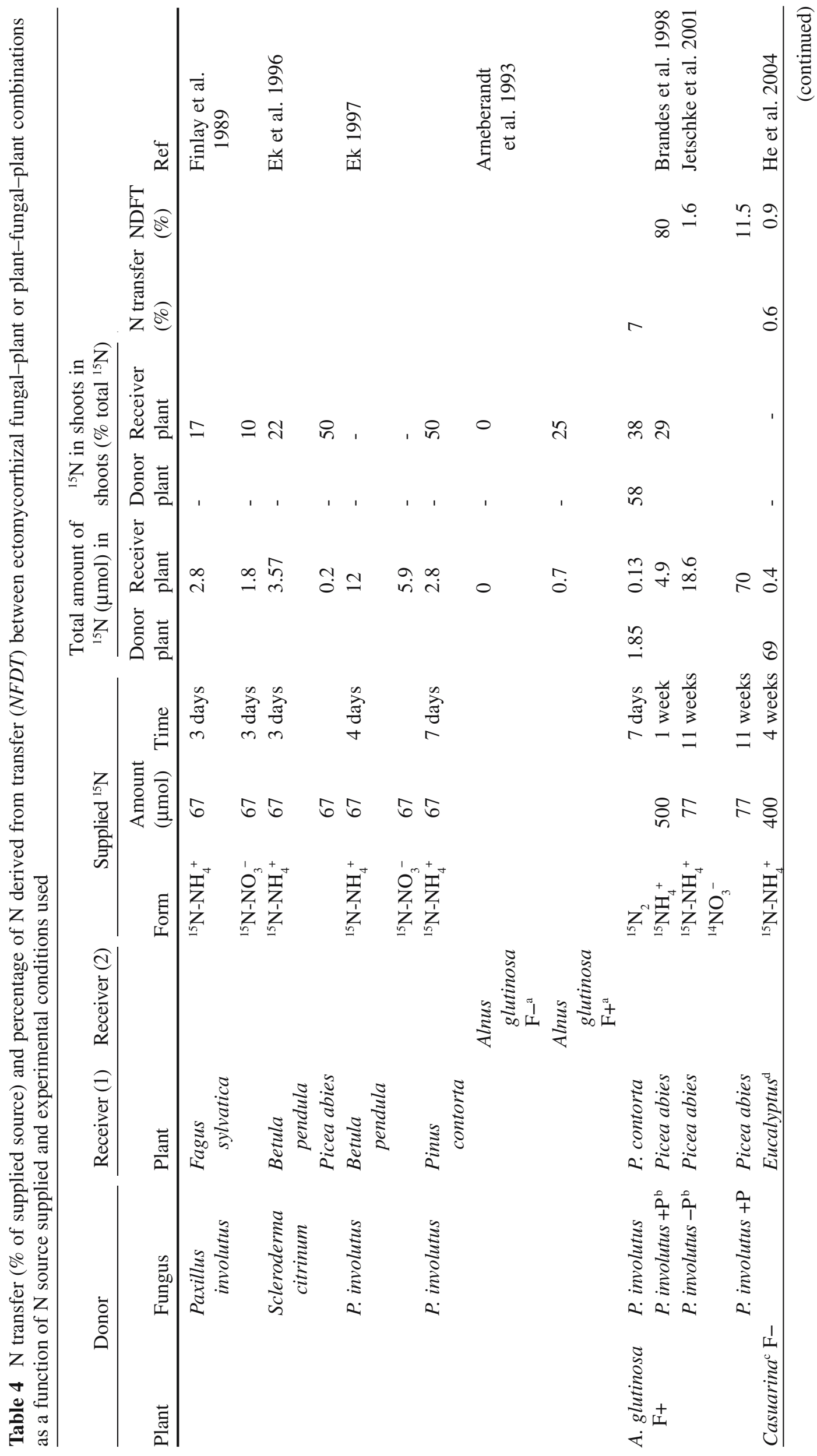




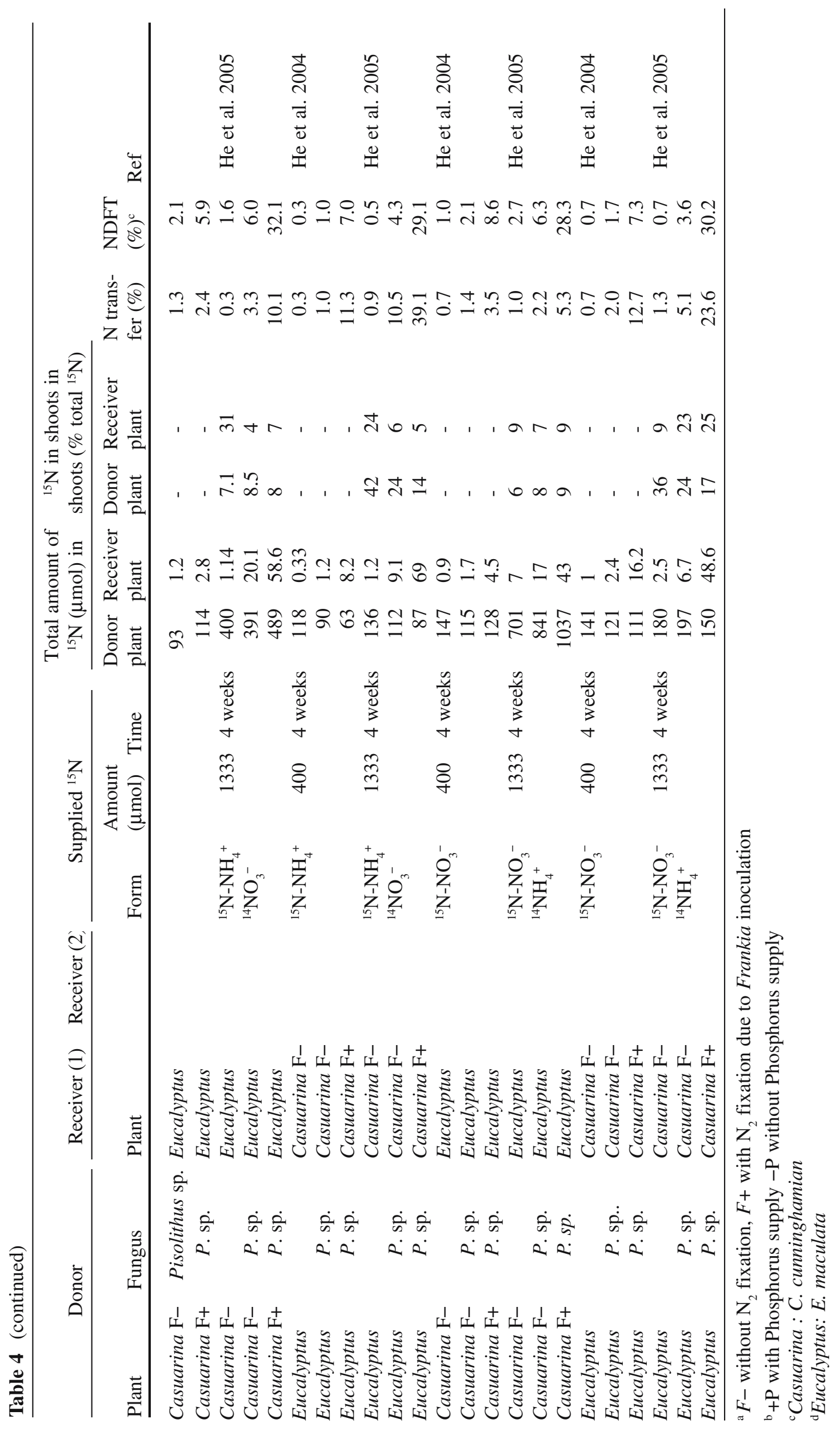


from the hyphae (Brandes et al. 1998; Jentschke et al. 2001) or the roots from two plant species connected by a common fungus (He et al. 2004, 2005). The main problem is to control exchange of nutrient by mass flow between the compartments through the nylon net. For example, this was done by adding greater solution volume to the plant compartment, creating a supression-promoting mass flow from the plant to the hyphal compartment, and preventing mass flow in the opposite direction. The presence of a negligible mass flow from hyphal to plant compartment was further demonstrated using aluminium as a tracer (Brandes et al. 1998). Using this sophisticated device, Brandes et al. (1998) showed that the addition of $\mathrm{NH}_{4}^{+}$ (together with $\mathrm{P}$ ) to the hyphal compartment for 14 weeks increased the total amount of $\mathrm{N}$ in the host-plant by $76 \%$. This figure was confirmed by adding ${ }^{15} \mathrm{~N}$ $\mathrm{NH}_{4}^{+}$during the last week of growth (Table 4), as the percentage of $\mathrm{N}$ derived from transfer in the mycorrhizal plants was estimated to be $81 \%$. These results indicate that the mycelium of $P$. involutus was able to take up and to translocate substantial amounts of $\mathrm{N}$ from the hyphal compartment to the $\mathrm{N}$-starved host plant that did not have access to the $\mathrm{N}$ source. Additional studies were carried out by the same group by supplying a complete nutritive solution containing $\mathrm{NH}_{4} \mathrm{NO}_{3} 0.3 \mathrm{mM}$ to the plant (Jentschke et al. 2001). The hyphal compartment was supplied with the same nutritive solution with or without P (Table 4). Irrespective the calculation method (mass balance or ${ }^{15} \mathrm{~N}$ labelling), the translocation of $\mathrm{N}$ from the fungus to the roots ceased in absence of phosphorus (Table 4). This indicates that the translocation of nonlimiting nutrient depends on simultaneous translocation of $\mathrm{P}$ (Jentschke et al. 2001). More recently, He and colleagues (Jentschke et al. 2004, 2005) studied N exchanges between a non-fixing (Eucalyptus maculata) and a $\mathrm{N}_{2}$-fixing (Casuarina cunninghamiana associated with Frankia) species connected together by the same ectomycorrhizal fungus, Pisolithus tinctorius. Nitrate and ammonium (4 mM of mineral N) were supplied separately for 5 months (He et al. 2004) or together for 11 months (He et al. 2005), to both plants grown in two-chamber compartmented pot. $\mathrm{N}$ transfer between compartments was studied in plants mycorrhizal or not, nodulated or not.

Mycorrhizal symbiosis and nitrogen fixation increased $\mathrm{N}$ accumulation by around 2 and 3, respectively, in Casuarina plants, whereas mycorrhizal symbiosis increased by around 1.4 and $1.8 \mathrm{~N}$ accumulation in Eucalyptus plants grown with non-nodulated and nodulated Casuarina, respectively (He et al. 2004, 2005). When ${ }^{15} \mathrm{~N}$ labelling was applied to nonmycorrhizal donor plants, ${ }^{15} \mathrm{~N}$ transfer to the receiver plant was low, irrespective of the $\mathrm{N}$ source (Table 4), indicating that the separation efficiently prevented the diffusion of solution between the two compartments. The percentage of $\mathrm{N}$ transfer from Casuarina, whether fixating or not, to Eucalyptus was rather low with values ranging from 1 to $5 \%$, except when plants were fed with ${ }^{15} \mathrm{~N} \mathrm{NH}_{4}^{+}-\mathrm{NO}_{3}{ }^{-}$(Table 4). However, due to the differences in the total $\mathrm{N}$ amount of the plants (Casuarina $>>$ Eucalyptus), $\mathrm{N}$ derived from transfer from nodulated Casuarina amounted to one-third of Eucalyptus $\mathrm{N}$ when both $\mathrm{N}$ sources were supplied together (Table 4). Similarly, the percentage of $\mathrm{N}$ transfer from Eucalyptus to non-nodulated Casuarina was rather low irrespective of the $\mathrm{N}$ source (Table 4). However, nodulation of Casuarina always dramatically increased $\mathrm{N}$ 
transfer from Eucalyptus (Table 4). Taking into account the bilateral exchanges, the main sink of $\mathrm{N}$ taken up by the mycelium was clearly Casuarina associated with Frankia, whatever the $\mathrm{N}$ source (Table 5). Thus, in experimental conditions where Eucalyptus and Casuarina plants were not starved for N, these data show that the contribution of the net $\mathrm{N}$ translocation between plants through the mycelium is very low. Surprisingly, the main sink of translocated $\mathrm{N}$ was the plant already containing the greatest amounts of N. As previously shown by Arnebrandt et al. (1993), the direction of these net $\mathrm{N}$ exchanges in favour of a $\mathrm{N}_{2}$-fixing plant could be due to the interdependence of nitrogen and phosphorus shown in the ectomycorrhizal symbiosis (Jentschke et al. 2001). Indeed, the biological nitrogen fixation is a high Pdemanding process (Israel 1987). Greater P requirements in nodulated Casuarina than in Eucalyptus could be filled up by a greater hyphal transport of $\mathrm{P}$ and a greater simultaneous translocation of $\mathrm{N}$.

Many studies have also been carried out in plants associated with endomycorrhizal fungi, especially AM species (Smith and Read 1997). The experimental devices used so far are based on containers with one root compartment separated from one or several hyphal compartments by a nylon mesh (e.g. Frey and Schüepp 1992, 1993; Hawkins et al. 1999, 2000; Johansen and Jensen 1996; Johansen et al. 1992, 1993, 1994; Tobar et al. 1994) or an impermeable membrane in polytetrafluoroethylene (PTFE) (Mäder et al. 2000) separating one root compartment from a hyphal one. Whereas these containers have been used to grow whole plants, transport of nitrogen by the hyphae of AM fungi was also studied using Ri T-DNA transformed carrot roots grown in vitro in two-compartment Petri dishes (Hawkins et al. 2000; Bago et al. 2001; Toussaint et al. 2004; Jin et al. 2005). As observed for ectomycorrhizal plants, the main problem is to control the transfer of nitrogen between hyphal and root compartments by mass flow, especially if nitrate is produced by nitrification from ${ }^{15} \mathrm{~N}_{-} \mathrm{NH}_{4}^{+}$(Johansen et al. 1992) or is supplied as the labeled $\mathrm{N}$ source (Tanaka and Yano 2005). This was achieved either by adding Nserve, a nitrification inhibitor (Johansen et al. 1992), using drought conditions (Tobar et al. 1994) or an air gap besides the nylon mesh (Johansen and Jensen 1996; Tanaka and Yano 2005). The use of a PTFE membrane reduced by $86 \%$ the passive ${ }^{15} \mathrm{~N}$ transport observed with a soil compartment system with nylon mesh alone and an additional root-free buffer zone (Frey et al. 1998). However, a measurable nitrate flux from the hyphal to the root compartment was shown to occur in nonmycorrhizal plants (Mäder et al. 2000). Obviously, the bicompartmented Petri dish is the best device as it makes it possible to control strictly the solution supplied to the external hyphae and the root and to follow its fate throughout the hyphae towards the root. The main limit of this experimental system consists of the absence of shoots. Uptake and translocation of ${ }^{15} \mathrm{~N}$ was demonstrated from $\mathrm{NH}_{4}^{+}$and for $\mathrm{NO}_{3}^{-}$, supplied separately or together. As shown by Johansen et al. (1994), plant N status greatly influenced the magnitude of $\mathrm{N}$ translocation from ${ }^{15} \mathrm{~N}-\mathrm{NH}_{4}^{+}$between Glomus intraradices and Cucumis sativus roots. The highest $\mathrm{N}$ translocation was observed in plants with the lowest $\mathrm{N}$ status, with 49 and $27 \%$ of the applied ${ }^{15} \mathrm{~N}$ recovered in mycorrhizal plants supplied with 100 and $400 \mathrm{mg} \mathrm{N}$, respectively (Johansen et al. 1994). This greater $\mathrm{N}$ translocation was in agreement with the 


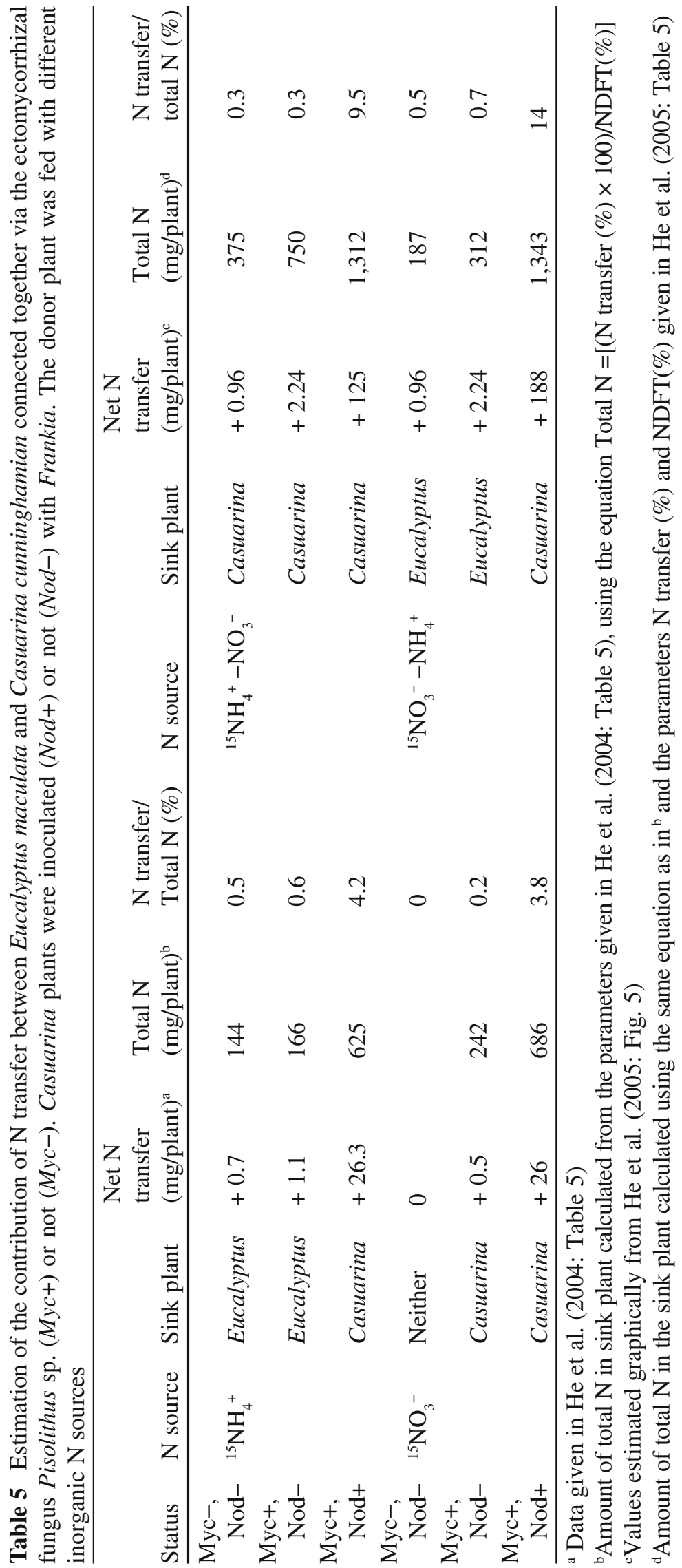


greatest growth improvment of plants due to mycorrhizal colonization. The same trend was observed regarding the magnitude of ${ }^{15} \mathrm{~N}$ transfer through Glomus mossae hyphae to tomato plants from uniformly labeled $\mathrm{NH}_{4} \mathrm{NO}_{3}$ (Mäder et al. 2000). Plants were grown at two $\mathrm{N}$ fertilizer concentration $\left(\mathrm{NH}_{4} \mathrm{NO}_{3}\right.$ at $1 \mathrm{mM}$ (low $\mathrm{N}$ ) or $3 \mathrm{mM}$ (high $\mathrm{N}$ ) ) in the root compartment. Flux of ${ }^{15} \mathrm{~N}$ from the hyphal compartment was estimated to contribute to ca. 42 and $24 \%$ of the total $\mathrm{N}$ of mycorrhizal plants fed with solution containing a low and a high $\mathrm{N}$ fertilizer concentration, respectively. As in ectomycorrhizal plants, potential transfer of $\mathrm{N}$ between $\mathrm{N}_{2}$ fixing and non fixing plants connected by a common AM mycelium was studied. Nodulated Trifolium alexandrinum roots connected to maize plants via Glomus intraradices hyphae were supplied with ${ }^{15} \mathrm{~N}_{2}$ for 5 days (Frey and Schüepp 1992). Although ${ }^{15} \mathrm{~N}$ excess measured in maize connected with trifolium via VAM was greater than that measured in nonconnected plants, the amounts of ${ }^{15} \mathrm{~N}$ transferred were small, accounting for less than $4 \%$ of the ${ }^{15} \mathrm{~N}$ fixed by Trifolium plants (Frey and Schüepp 1992). Net $\mathrm{N}$ transfer of $\mathrm{N}$ between Pisum sativum and Hordeum vulgare associated with $G$. intraradices grown in compartmented devices was also studied when $\mathrm{NH}_{4}^{+}$ was supplied to the roots of either species (Johansen and Jensen 1996). Net transfer of ${ }^{15} \mathrm{~N}$ from $\mathrm{NH}_{4}^{+}$supplied to pea roots was detected in barley when plants are associated with a mycorrhizal fungus. However, value of $\mathrm{N}$ derived from transfer was very low $(0.6 \%)$. In addition, this net transfer was almost insignificant since $\mathrm{N}$ was also transferred in the reverse direction. Net ${ }^{15} \mathrm{~N}$ transfer to the receiver plant increased when the shoots of the donor plant were removed, amounting to $15 \%$ of the donor-root $\mathrm{N}$ after 18 days, while nonmycorrhizal receiver plants contained only 4\% (Johansen and Jensen 1996). These data are in agreement with the observation reported by Johanssen et al. (1994) who found that $G$. intraradices hyphae adjacent to heavily labeled roots of cucumber contained very low amounts of ${ }^{15} \mathrm{~N}$, indicating that only small amounts of $\mathrm{N}$ were transfered from the roots to the external hyphae. Thus, the net transport of $\mathrm{N}$ appears to be much higher from the hyphae to the living roots than in the reverse direction. This could explain the limited role of AM-mycorrhizal hyphae in interplant $\mathrm{N}$ transfer.

\subsection{N Transfer: Translocated Compounds and Molecular Events}

The use of mass spectrometry coupled to the supply of ${ }^{15} \mathrm{~N}$ labeled substrates specifically to the fungus made it possible to follow the enrichment of individual amino acid all the way from the extramatrical hyphae to the shoot of the host in ectomycorrhizal (Finlay et al. 1988, 1989; Arnebrandt et al. 1993) or AM (Govindarajulu et al. 2005; Jin et al. 2005) associations. In ectomycorrhizal plants, a feeding period of $73 \mathrm{~h}$ with ${ }^{15} \mathrm{~N}_{-} \mathrm{NH}_{4}{ }^{+}$resulted in high proportions of ${ }^{15} \mathrm{~N}$-labeled free glutamate/glutamine, aspartate/asparagine, and alanine in the mycelium of Rhizopogon roseolus, Suillus bovinus, Pisolithus tinctorius, and Paxillus involutus, although labeled aspartate/asparagine were not found in this last species (Finlay et al. 1988). The same results were found when ${ }^{15} \mathrm{NH}_{4}^{+}$or ${ }^{15} \mathrm{NO}_{3}^{-}$was supplied to 
the hyphae of P. involutus associated with Fagus sylvatica (Finlay et al. 1989). However, high labeling was also found in aspartate/asparagine in the mycelium (Finlay et al. 1989). Other measurements carried out with $P$. involutus associated with two host plants (Pinus contorta and Alnus glutinosa) showed that citrulline and glutamine were the amino acids with the highest ${ }^{15} \mathrm{~N}$ concentrations in the mycelium and in all parts of the system when ${ }^{15} \mathrm{NH}_{4}^{+}$was supplied (Arnebrandt et al. 1993). Thus, these data strongly suggested that the form of $\mathrm{N}$ translocation throughout the hyphae could be glutamate/glutamine (Chalot and Brun 1998). The most convincing data about the mechanisms involved in translocation of $\mathrm{N}$ in the hyphae and release at the hyphae-host cell interface have been obtained in AM symbiosis (Govindarajulu et al. 2005; Jin et al. 2005). It was first proposed by Bago et al (2001) that the synthesis of arginine and its breakdown through the urea cycle could ensure an efficient net translocation of $\mathrm{N}$ together with the recycling of carbon. This novel metabolic pathway was nicely demonstrated by using the association AM-carrot roots grown in vitro in two-compartment Petri dishes. The labeling with stable isotopes showed that arginine, representing more than $90 \%$ of the total free amino acid pool in the extraradical mycelium (ERM) became heavily labeled after the supply of ${ }^{15} \mathrm{NO}_{3}{ }^{-}$or ${ }^{15} \mathrm{NH}_{4}^{+}$. In addition to ${ }^{15} \mathrm{~N}$ supply, the ERM was fed with ${ }^{13} \mathrm{C}_{2}$ acetate. Free amino acids in the ERM became heavily labeled, with $34-77 \%$ of the molecules of the three abundant amino acids (arginine, glutamate and aspartate) having one or more ${ }^{13} \mathrm{C}$ atoms. In contrast, proteins from the colonized roots did not become detectably labeled with ${ }^{13} \mathrm{C}$ under these conditions, strongly suggesting that no carbon is transferred to the host cell. Feeding the ERM with ${ }^{13} \mathrm{C}_{\mathrm{U} 6}$ arginine indicated that arginine was transported intact from the ERM towards the IRM and showed the absence of ${ }^{13} \mathrm{C}$ arginine labeling in the proteins extracted from the roots. In contract, supplying ${ }^{15} \mathrm{~N}$ arginine to the ERM resulted in ${ }^{15} \mathrm{~N}$ labeling in all the free amino acids in the root tissue, including those present at high levels in uncolonized roots and at low levels in the ERM. Taken together, these data confirmed that (1) the nitrogen but not the carbon of arginine is transferred from fungus to host accross the host-fungus interface (Govindarajulu et al. 2005; Jin et al. 2005), and (2) arginine must be broken down to release $\mathrm{NH}_{4}^{+}$. This could be ensured by the operation of arginase, releasing ornithine and urea, and urease releasing $\mathrm{NH}_{4}^{+}$and $\mathrm{CO}_{2}$ from urea. Ornithine (and $\mathrm{NH}_{4}^{+}$) could be then metabolized through ornithine amino transferase (OAT) for amino acid synthesis in the IRM. This metabolic route is supported by a higher expression of genes putatively encoding fungal urease, OAT and ammonium transporter in IRM (in mycorrhizal roots) than in ERM (Govindarajulu et al. 2005).

From the available data in the literature, it is clear that the mechanisms of exchange of $\mathrm{N}$ between fungal and plant cells are not yet fully understood. Exchanges of $\mathrm{N}$ mean that $\mathrm{N}$-containing molecules or ions have to permeate through the fungal plasma membrane because there is no direct connection between the cytosol of fungal and plant cells, such as plasmodesmata making the cortical symplasm. So far, our knowledge about the solutes (identification and concentration) present in the apoplastic space are completely lacking and very difficult to obtain experimentally. The use of molecular approaches, offering a tool to study specifically the expression 
of genes from fungal or plant origin in the mycorrhizal tissue, appears as an invaluable strategy to gain new insights about the pathways involved in both partners and thus hypothesize which $\mathrm{N}$ compounds are transferred at the fungus-root interface. As stated before, ammonium resulting from the breakdown of translocated arginine is transferred at the root-fungus interface in AM symbiosis. However, as discussed by Chalot et al. (2006), the fungal Amt gene which was found overexpressed in IRM compared to ERM is not compatible with a release of $\mathrm{NH}_{4}^{+}$into the apoplast through the encoded Amt transporter. Rather, such a transporter would ensure the reuptake of any molecule of ammonium from the apoplast back to the fungal cytosol, resulting in a futile cycling of inorganic $\mathrm{N}$ and probably in an inefficient $\mathrm{N}$ transfer (Chalot et al. 2006). In addition, in ectomycorrhizal symbiosis, even if a net translocation of ${ }^{15} \mathrm{~N}$ in the shoots of the host-plant was demonstrated, the pathway of $\mathrm{N}$ translocation and exchange probably does not involve arginine because, contrary to AM hyphae, this amino acid is not a major form of $\mathrm{N}$ accumulation in the mycelium or in the mycorrhizal root (see, e.g., Finley et al. 1989). Therefore, glutamine and/or asparagine appear as the best candidates to sustain the metabolic pathway leading to $\mathrm{N}$ release into the apoplastic space of Hartig net. Nevertheless, it should be noticed that urea was assayed in ectomycorrhizal tips (ECM) and in extraradical mycelium (EM) of Paxillus involutus associated with Betula pendula seedlings grown in microscosms (Morel et al. 2005). The concentration of urea was the same in ECM and EM $(1 \mu \mathrm{mol} / \mathrm{g} \mathrm{dwt})$ and constituted the second main $\mathrm{N}$ compound in ECM (the first one was glutamate) and the main $\mathrm{N}$ compound in EM. These data suggest that urea cycle could also be involved in $\mathrm{N}$ transfer. However, nontargeted studies did not confirm this hypothesis. Messenger RNAs extracted from ECM and EM were hybridized to microarrays made from genes specifically expressed in the free-living mycelium fed with Gln (N derepression, i.e., low internal amino acid content) or with $\mathrm{NH}_{4}^{+}(\mathrm{N}$ repression, i.e., high internal amino acid content). The results obtained showed that 66 genes (of 1,200 used to make the microarray) were found to be differentially expressed in ECM and EM. In ECM, the gene that was the most upregulated (24fold) was identified as encoding a putative phosphatidylserine decarboxylase (Psd), an enzyme which could contribute to membrane remodeling during ectomycorrhiza formation. Surprisingly, genes coding for urea (Dur 3) and spermine (Tpo3) transporters were upregulated 4.1- and 6.2-fold in EM. Morel et al. (2005) hypothesize that these transporters could facilitate the translocation of nitrogen compounds within the EM network. It is possible that the selection of a given fungal gene population realized in the fungus grown in pure culture hampered the discovery of the genes involved in $\mathrm{N}$ exchanges. However, it should be noticed that genes with no known homology were also found to be upregulated in ECM and in EM. These genes of unknown function might be those involved in $\mathrm{N}$ exchanges, underlying the need to discover their function.

The molecular data available so far indicate that organic $\mathrm{N}$ (amino acids) as well as inorganic $\mathrm{N}\left(\mathrm{NH}_{3} / \mathrm{NH}_{4}^{+}\right)$could be exchanged in ectomycorrhizal symbiosis (Table 6). Acting in favor of organic $\mathrm{N}$ exchange is the strong repression of HcGAPl (coding a broad amino acid spectrum transporter) in ectomycorrhizal roots of Hebeloma cylindrosporum-Pinus pinaster. The release of amino acid could be ensured by a 


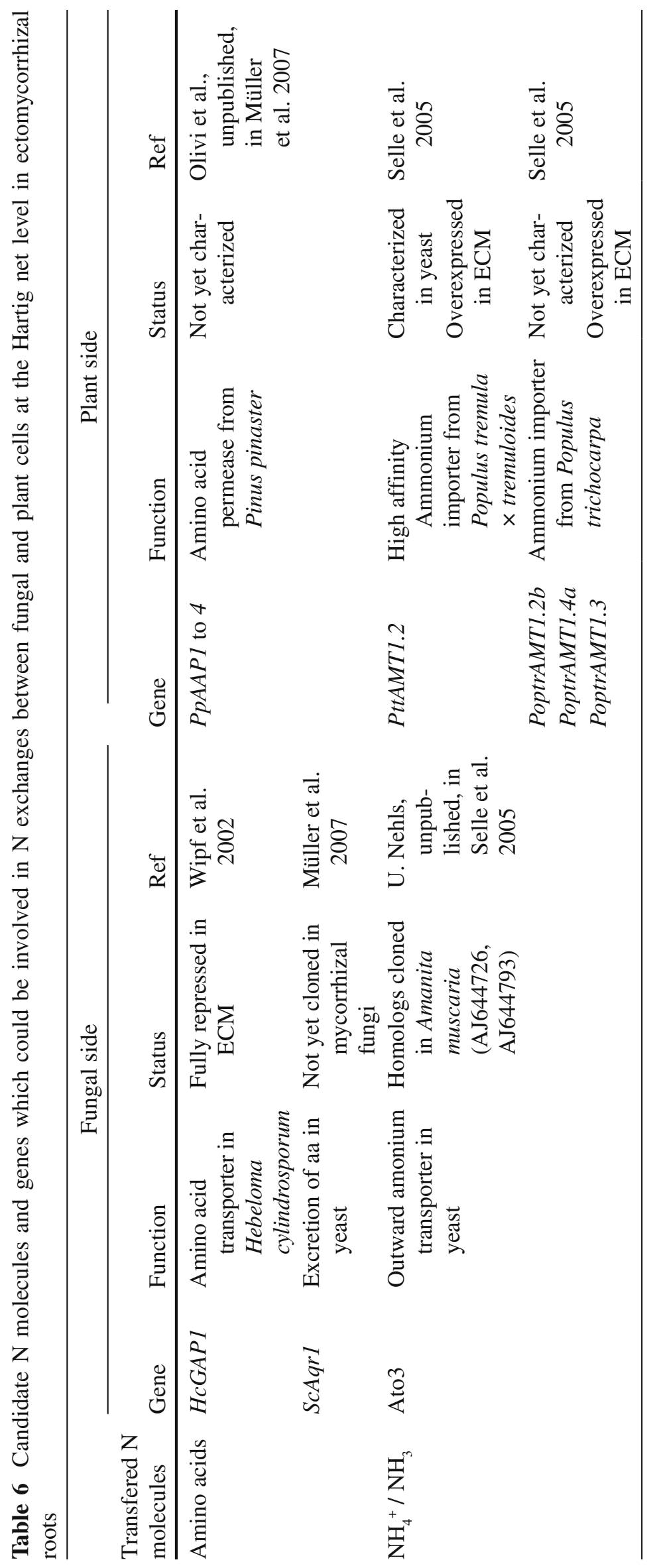


transporter from the same family as Aqr1 recently characterized in Saccharomyces cerevisiae, which is involved in excretion of amino acids (Chalot et al. 2006; Müller et al. 2007). Its homolog could be searched in EST libraries (Hebeloma cylindrosporum; Wipf et al. 2003; Lambilliotte et al. 2004) and in the database coming from sequencing project of the ectomycorrhizal fungus Laccaria bicolor (http://genome. jgi-psf.org/Lacbi1/Lacbi1.home.html). In addition, amino acid permeases of the hostplant, $P$. pinaster, have been identified. Their functional characterization and their pattern of expression in ECM will greatly help to know whether or not the corresponding transporters could play a role to take up the released organic $\mathrm{N}$ in the apoplastic space. On the other hand, ammonium release at the level of Hartig net is also supported by results obtained with the association between Amanita muscaria and Poplar roots (Table 6; Selle et al. 2005). As indicated by these authors, two genes homologous to a supposed ammonium export protein of $S$. cerevisiae, Ato3, are expressed in A. muscaria (Table 6). In agreement with the putative efflux of $\mathrm{NH}_{4}^{+}$into the apoplast, the Populus high affinity ammonium transporter gene PttAMT1.2 was found overexpressed in ectomycorrhizal roots. Three other Populus genes coding putative ammonium transporters were also found to be overexpressed in ECM (Selle et al. 2005).

However, the form of inorganic $\mathrm{N}\left(\mathrm{NH}_{3}\right.$ or $\left.\mathrm{NH}_{4}^{+}\right)$and the molecular mechanism responsible for inorganic $\mathrm{N}$ efflux are still matter of debate. Chalot et al. (2006) proposed several pathways that could be followed by inorganic $\mathrm{N}$ to be extruded from fungal cells, either by passive efflux of the deprotonated form or by protein-mediated mechanisms. Alternatively, excess ammonia could be stored in intracellular vesicles, either by diffusion of $\mathrm{NH}_{3}$ or by active transport of $\mathrm{NH}_{4}^{+}$(Chalot et al. 2006). It is important to keep in mind that, due to the $\mathrm{pKa}$ of $\mathrm{NH}_{3}(9.25)$, the value of cytosolic $\mathrm{pH}$ will have a huge effect on the ratio $\mathrm{NH}_{4}^{+}: \mathrm{NH}_{3}$. For example, $\left[\mathrm{NH}_{4}^{+}\right]$will be 177 or 44-fold higher than $\left[\mathrm{NH}_{3}\right]$ in the cytosol at $\mathrm{pH} 7$ and 7.5, respectively. It is generally assumed that cytosolic $\mathrm{pH}$ is around 7, indicating that $\mathrm{NH}_{4}^{+}$must be largely predominant over $\mathrm{NH}_{3}$. On the other hand, due to its potential decoupling activity, free $\mathrm{NH}_{4}^{+}$cannot accumulate to a great extent in the cytosol. Thus, the active transport of $\mathrm{NH}_{4}^{+}$via an Amt-mediated transport system into acidified vesicles would ensure the compartmentalization of excess of inorganic $\mathrm{N}$, as proposed by Chalot et al. (2006). These $\mathrm{NH}_{4}^{+}$-loaded vesicles could then move via microtubules to the symbiotic membrane where they would fuse with the plasma membrane and release ammonium into the interfacial apoplast (Chalot et al. 2006). Voltage-dependent cation channels such as proposed for export of fixed $\mathrm{NH}_{4}^{+}$between endosymbiotic rhizobia bacteria and the legume host (Roberts and Tyerman 2002) could be involved in export of inorganic $\mathrm{N}$ from the symbiotic cell (Chalot et al. 2006).

\subsection{N Transfer in Mycorrhizal Plants: The Situation in the Real Life}

Despite the fact that the delivery of nitrogen taken up by the fungus to the plant, whether associated with ecto- or AM-mycorrhizal fungi, was demonstrated many times, data in the literature also questioned the quantitative contribution of hyphal 
$\mathrm{N}$ transfer on whole $\mathrm{N}$ plant budget. In the ectomycorrhizal symbiosis, for example, the data published with the association between Hebeloma cylindrosporum and Pinus pinaster illustrate this point. Grown in containers with a high $\mathrm{N}$ concentration (5 mM) supplied either as $\mathrm{NH}_{4}^{+}, \mathrm{NO}_{3}{ }^{-}$or L-glutamate, nonmycorrhizal plants grew better than mycorrhizal ones, except with organic $\mathrm{N}$ supply where the reverse situation was observed. Plants fed with mineral $\mathrm{N}$ accumulated less $\mathrm{N}$ than nonmycorrhizal ones. Measurement of biomass and $\mathrm{N}$ accumulation in the fungus showed that considerable amounts of $\mathrm{N}$ were immobilized in the fungus, whatever the $\mathrm{N}$ source (Plassard et al. 2000). Therefore, these results questioned the occurrence of $\mathrm{N}$ transfer between the fungus and the host, particularly when nitrate was supplied. However, recent molecular studies quantified the level of transcripts from plant and fungal nitrite reductases, and fungal ammonium transporter HcAmt1 in control uninoculated roots, extraradical mycelia and ECM formed by either wild type or nitrate reductase deficient fungal strains (Bailly et al. 2007). Supplied with $1 \mathrm{mM}$ $\mathrm{NO}_{3}^{-}$, the plant nitrite reductase was found repressed by the two wild type strains and fully expressed by the nitrate reductase-deficient strain. As the plant nitrite reductase is highly repressed by reduced $\mathrm{N}$ and fully expressed by $\mathrm{NO}_{3}^{-}$, these data strongly suggest that this fungal species is able to translocate reduced $\mathrm{N}$ to the host plant after $\mathrm{NO}_{3}^{-}$reduction by fungal nitrate and nitrite reductases. In contrast, the positive effect of ectomycorrhizal symbiosis on growth and $\mathrm{N}$ accumulation by the host plant has been clearly demonstrated in early experiments carried out with organic $\mathrm{N}$ as the $\mathrm{N}$ source (see Section 2.1). However, in this case, an indirect effect of the fungus on $\mathrm{N}$ utilization by the plant cannot be excluded. Fungal cells could release $\mathrm{NH}_{4}^{+}$into the medium from the hydrolysis of L-glutamate (as shown in pure culture; see Quoreshi et al. 1995). Available $\mathrm{NH}_{4}^{+}$could then be taken up directly by the roots grown in the same medium, explaining the better growth of mycorrhizal plants. In addition, it is clear that variations among fungal species might exist regarding their efficiency to translocate $\mathrm{N}$ to their host plant. However, as shown in Table 4, most of the studies aiming at quantifying $\mathrm{N}$ transfer between the fungus and the host plant have been only carried out on a few species such as Paxillus involutus or Pisolithus tinctorius. Although not specifically designed to assess the $\mathrm{N}$ transfer between the mycelium and the host plant, a recent study carried out in the field by Nara (2005) indicates strong differences between species to help young seedlings of Salix reinii connected to mother plants to grow in volcanic desert at Mount Fuji, Japan (Nara 2005). Eleven native fungal species were used to connect 1 -year mother plant with young seedlings of $S$. reinii. After 5 months of growth, young seedlings were harvested and their biomass, $\mathrm{N}$ and $\mathrm{P}$ contents measured. Results obtained showed that nutrient acquisition and growth of seedlings connected to mycelial network were improved with most fungal species. From these data, we did the following calculations: firstly, we divided the total amount of $\mathrm{N}$ and $\mathrm{P}$ accumulated in the whole seedlings by the root dry weight to get the accumulation rates of $\mathrm{N}$ and $\mathrm{P}$ by taking into account the effect of mycorrhizal symbiosis on root growth; secondly, we divided each $\mathrm{N}$ and $\mathrm{P}$ accumulation rate by that of nonmycorrhizal control plants. Such a ratio will give indication on the possible supplementary $\mathrm{N}$ or $\mathrm{P}$ accumulation in the host plant through mycelial uptake and/ or translocation of nutrients from the mother tree. As shown in Fig. 1, the effect of 


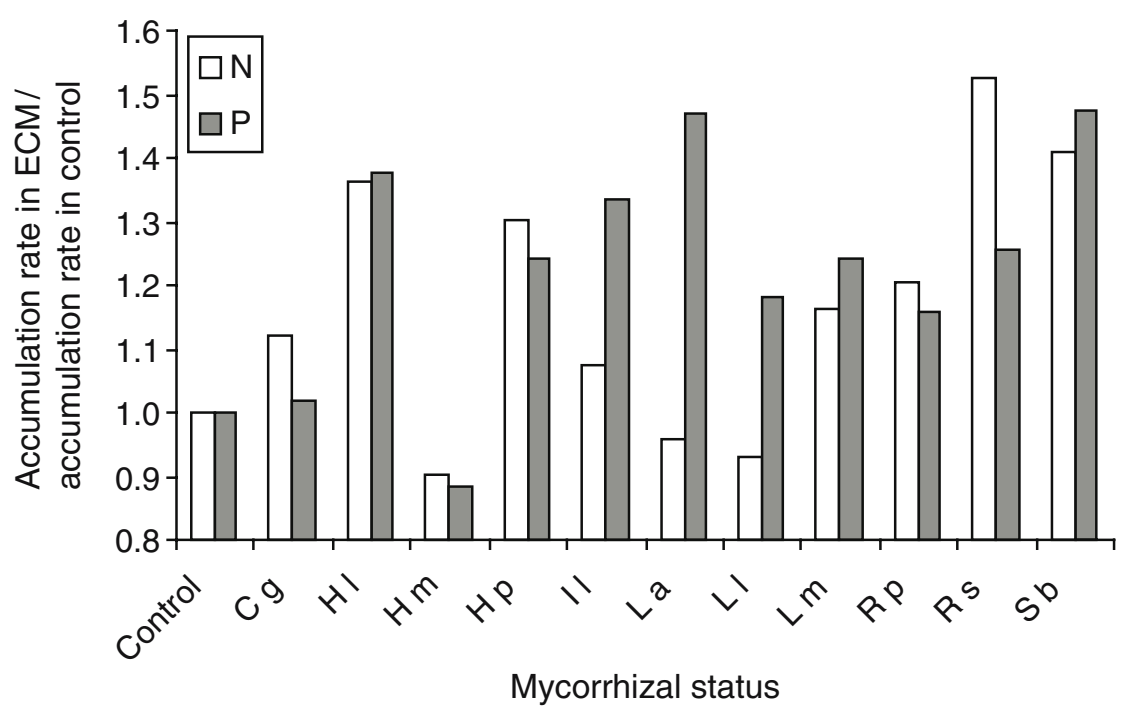

Fig. 1 Variability of enhancement of $\mathrm{N}$ and $\mathrm{P}$ accumulation rates in young seedlings of Salix reinii connected to mother trees via different native ectomycorrhizal species using data published by Nara (2005). Given are the ratios calculated between accumulation rates of N or P (total amounts of $\mathrm{N}$ or $\mathrm{P}$ in whole seedlings divided by root dry weigth) in ectomycorrhizal plants to that of nonmycorrhizal (control) plant. A ratio $<1$ indicates a negative effect whereas a ratio $>1$ indicates a positive effect of ectomycorrhizal symbiosis. The ectomycorrhizal species were $\mathrm{Cg}$ Cenococcum geophilum, Hl Hebeloma leucosarx, Hm H. mesophaeum, Hp H. pusillum, Il Inocybe lacera, La Laccaria amethystina, Ll L. laccata, Lm Laccaria murina, Rp Russula pectinatoides, R.s R. sororia, Sb Scleroderma bovista

individual species varied strongly among them, with: a ratio $<1$ only for $\mathrm{N}$ (Laccaria amethystina, L. laccata), suggesting a net transfer of $\mathrm{P}$ but not of $\mathrm{N}$; a ratio $<1$ for $\mathrm{N}$ and $\mathrm{P}$ (Hebeloma mesophaeum), suggesting no net transfer of nutrients for this species; a ratio $>1$ for $\mathrm{N}$ and $\mathrm{P}$ (Hebeloma leucosarx, H. pusillum, Laccaria murina, Russula pectinatoides, R. Sororia, Scleroderma bovista), indicating simultaneous transfer of $\mathrm{N}$ and $\mathrm{P}$; or a ratio slightly $>1$ for $\mathrm{N}$ (Cenococcum geophilum and Inocybe lacera) suggesting a low effect on $\mathrm{N}$ accumulation that is independent of a P effect. These data clearly indicate that interspecific variations of efficiency in $\mathrm{N}$ (and P) capture and translocation exist among the fungal species in situ and raise the question of the extrapolation of results from a few "laboratory" species (such as Paxillus involutus or Pisolithus sp.) to the real world.

The same question can be raised for AM plants. Indeed, studies carried out with in vitro system showed clearly that huge amounts of $\mathrm{N}$ taken up by extraradical hyphae are transferred to the carrot roots (up to 50\%; Govindarajulu et al. 2005). However, a set of published data indicates that the contribution of AM to the $\mathrm{N}$ nutrition of the host plant is low. For example, the study of Reynolds et al. (2005) manipulated $\mathrm{N}$ availability (control vs inorganic and organic forms) and AM species (control vs four AM species) for five old-field perennials grown individually in a glasshouse under $\mathrm{N}$-limiting conditions. Although not quantifying $\mathrm{N}$ transfer between the fungus and the plant, the results showed that AM fungi were at best neutral and that some AM species depressed growth for some plant species, suggesting 
that $\mathrm{AM}$ fungi did not promote $\mathrm{N}$ acquisition at low $\mathrm{N}$ supply. However, the fact that this study was carried out in a constrained rooting volume may have favored the competition between the hyphae and the root for $\mathrm{N}$ uptake, such conditions promoting growth-depressing effects of AM fungi in responsive plant species. In another study, Hawkins et al. (1999) showed that additional supply of $\mathrm{NH}_{4} \mathrm{NO}_{3}$ $(2 \mathrm{mM})$ only to the hyphae of Glomus mossae increased by $14 \%$ the total amount of $\mathrm{N}$ in wheat plants, with 84.1 and $73.5 \mathrm{mg} \mathrm{N} /$ plant in mycorrhizal and nonmycorrhizal plants, respectively, giving a net increase of $10.6 \mathrm{mg} \mathrm{N} /$ plant due to AM. On the other hand, AM-plants supplied with $\mathrm{NH}_{4} \mathrm{NO}_{3} 2 \mathrm{mM}$ in both the hyphal and root compartment contained 50\% more $\mathrm{N}$ than NM plants with 371 and $250 \mathrm{mg} \mathrm{N} /$ plant in AM and control plants, respectively. From their results, the authors concluded that mycorrhizal $\mathrm{N}$ uptake may help plants to survive during periods of low soil $\mathrm{N}$ supply but is not a mechanism to sustain high plant growth rates in agricultural or horticultural crops. However, it should be underlined that AM plants make a better use of $\mathrm{N}$ supplied at a high concentration than nonmycorrhizal ones, contrary to what was observed in ectomycorrhizal Pinus pinaster plants (see above). The same type of experiment was carried out with $\mathrm{NO}_{3}{ }^{-}$as the sole $\mathrm{N}$ source supplied at $2 \mathrm{mM}$ to the hyphal compartment and at 0.2 or $2 \mathrm{mM}$ to the wheat root compartment (Hawkins et al. 2000). In this case, there was no significant difference between the shoot or root dry weight or $\mathrm{N}$ concentration of AM- and non-AM-plants (Hawkins et al. 2000). These results are in agreement with those published by Tanaka and Yano (2005) who showed that only $2.9 \%$ of the shoot-N of maize plants colonized by Glomus aggregatum was derived from nitrate-N added to the hyphal compartment while $74 \%$ was derived from the slow-release urea. Curiously, intraradical hyphae isolated from roots contained appreciable amount of ${ }^{15} \mathrm{~N}$ in the cell walls even when ${ }^{15} \mathrm{NO}_{3}^{-}$was the $\mathrm{N}$ source. The main cell wall $\mathrm{N}$ compound is chitin that is synthesized from reduced $\mathrm{N}$, indicating that this fungal species is able to assimilate $\mathrm{NO}_{3}^{-}$. However, these results are not in agreement with those of Govindarajulu et al. (2005) who showed that ${ }^{15} \mathrm{~N}$ from nitrate was translocated from the extraradical hyphae of Glomus intraradices to carrot roots. These discrepancies could be explained by a much lower rate of ${ }^{15} \mathrm{~N}$ assimilation from ${ }^{15} \mathrm{~N}$-nitrate than from ${ }^{15} \mathrm{~N}$ urea, leading to concentration of amino acids that could be used for ${ }^{15} \mathrm{~N}$ translocation such as arginine (Govindarajulu et al. 2005; Jin et al. 2005) much lower than that produced from urea assimilation. In agreement with this hypothesis, intraradical hyphae grown with urea contained 6 times more ${ }^{15} \mathrm{~N}$ in their cell walls than those grown with nitrate (Tanaka and Yano 2005). This observation is in favor of a much greater $\mathrm{N}$ assimilation from supplied urea than from nitrate.

\section{Conclusions}

From the available data in the literature, it can be concluded that the mycorrhizal fungi are able to use a variety of $\mathrm{N}$ sources as their host-plants, although individual differences exist among fungal and plant capacities. Clear experimental evidence 
exists indicating that $\mathrm{N}$ taken up by the hyphae in the external medium is translocated throughout the hyphae towards the mycorrhizal root, leaves the fungal cells and is finally taken up by the root cell. However, despite the demonstration of this pathway in AM carrot roots grown in vitro, many questions remained to be answered, especially regarding the molecular mechanisms involved in the exchange of $\mathrm{N}$-containing molecules at the level of root-fungus interface as well as how these mechanisms are regulated. To address these questions, which deal with the identification of molecular events resulting in the exchange of $\mathrm{N}$, two main approaches could be used that can be divided in untargeted versus targeted ones. The untargeted approach, microarray, should take its full power with the complete sequencing and annotation of genomes (i.e., the complete genome of Laccaria bicolor, http://genome.jgi-psf. org/Lacbi1/Lacbi1.home.html; Glomus intraradices, http://www.jgi.doe.gov/ sequencing/DOEmicrobes.html; Populus trichocarpa (Tuskan et al. 2006). Analysis of the whole genomes of both partners should help us to discover new genes and to study their expression in function of different $\mathrm{N}$ supplies. However, the main "bottle-neck" of this approach is the need to establish the function of unknown genes whose expression is specifically modified by the symbiosis. This could be achieved using functional complementation of yeast. Also, the localization of gene expression (IRM, ERM) and localization of the protein in the cell will be helpful in understanding their putative role in the symbiosis. In situ hybridization (Kaldorf et al. 1998), in situ RT-PCR (Van Aarle et al. 2007) or protein labeling using antibodies (Montanini et al. 2006) could be used to gain new information about the localization of any interesting genes. Besides these untargeted approaches, targeted ones could also be used, especially in combination with labeling experiments and differential tissue analysis such as the ones carried out in AM symbiosis (Govindarajulu et al. 2005; Jin et al. 2005). It seems very important to establish the pathways of $\mathrm{N}$ transfer as a function of the $\mathrm{N}$ source and their concentrations, as those used in laboratory experiments are generally much higher than those assayed in the soil solution (compare Tables 1 and 4). Indeed, if we are able to determine the key metabolites whose concentration determines the efficiency of mycorrhizal symbiosis on $\mathrm{N}$ transfer to the host cell, it will be easier to extend our knowledge to other fungal species than the few ones which have been studied over the last years, hence contributing to a better understanding of the ecological role of mycorrhizal symbiosis in the field.

\section{References}

Abuzinadah RA, Read DJ (1989) The role of proteins in the nitrogen nutrition of ectomycorrhizal plants IV. The utilization of peptides by birch (Betula pendula L.) infected with different mycorrhizal fungi. New Phytol 112:55-60

Andersson P, Berggren D (2005) Amino acids, total organic and inorganic nitrogen in forest floor soil solution at low and high nitrogen input. Water Air Soil Pollut 162:369-384

Arnebrandt K, Ek H, Finlay R, Söderström B (1993) Nitrogen translocation between Alnus glutinosa (L.) Gaertn. Seedlings inoculated with Frankia sp. and Pinus contorta Doug. Ex Loud seedlings connected by a common ectomycorrhizal mycelium. New Phytol 124:231-242 
Attiwill PM, Adams MA (1993) Nutrient cycling in forests. New Phytol 124:561-582

Aubert M, Bureau F, Vinceslas-Akpa M (2005) Sources of spatial and temporal variability of inorganic nitrogen in pure and mixed deciduous temperate forests. Soil Biol Biochem 37:67-79

Bago B, Shachar-Hill Y, Pfeffer PE (2001) Could the urea cycle be translocating nitrogen in the arbuscular mycorrhizal symbiosis? New Phytol 149:4-8

Bailly J, Debaud JC, Verner MC, Plassard C, Chalot M, Marmeisse R, Fraissinet-Tachet L (2007) How does a symbiotic fungus modulate expression of its host-plant nitrite reductase? New Phytol 175:155-165.

Bajwa R, Abuarghub S, Read DJ (1985) The biology of mycorrhiza in the Ericaceae. X. The utilization of proteins and the production of proteolytic-enzymes by the mycorrhizal endophyte and by mycorrhizal plants. New Phytol 101:469-486

Barber SA (1995) Soil nutrient availability, a mechanistic approach, 2nd edn. Wiley, New York

Bedell JP, Garnier A, Pireaux JC, Chalot M, Brun A, Botton B (1994) Study of enzymes involved in nitrogen-metabolism of Douglas-Laccaria laccata ectomycorrhizas. Acta Bot Gallica 141:483-490

Bending GD, Read DJ (1996) Nitrogen mobilization from protein-polyphenol complex by ericoid mycorrhizal fungi. Soil Biol Biochem 28:1602-1612

Bending GD, Read DJ (1997) Lignin and soluble-phenolic degradation by ectomycorrhizal and ericoid mycorrhizal fungi. Mycol Res 101:1348-1354

Bendjia M, Rikirsch E, Müller T, Morel M, Corratgé C, Zimmermann S, Chalot M, Frommer WB, Wipf D (2006) Peptide uptake in the ectomycorrhizal fungus Hebeloma cylindrosporum: characterization of two di- and tri-peptide transporters (HcPTR2A and B). New Phytol 170:401-410

Bennett JN, Prescott CE (2004) Organic and ionrganic nitrogen nutrition of western red cedar, western hemlock and sala in minearl N-limited cedar-hemlock forests. Oecologia $141: 468-476$

Botton B, Dell B (1994) Expression of glutamate dehydrogenase and aspartate aminotransferase in eucalypt ectomycorrhizas. New Phytol 126:249-257

Boukcim H, Plassard C (2003) Juvenile nitrogen uptake capacities and root architecture of two open-pollinated families of Picea abies. Effects of nitrogen source and ectomycorrhizal symbiosis. J Plant Physiol 160:1211-1218

Brandes B, Godbold D, Kuhn A, Jentschke G (1998) Nitrogen and phosphorus acquisition by the mycelium of the ectomycorrhizal fungus Paxillus involutus and its effect on host nutrition. New Phytol 140:735-743

Burke RM, Cairney JWG (1998) Carbohydrate oxidases in ericoid and ectomycorrhizal fungi: a possible source of Fenton radicals during degradation of lignocellulose. New Phytol 139:636-645

Cairney JWG, Sawyer NA, Sharples JM, Meharg AA (2000) Intraspecific variation in nitrogen use utilisation by isolates of the ericoid mycorrhizal fungus Hymenoscyphus ericae (Read) Korf and Kernan. Soil Biol Biochem 32:1319-1322

Chalot M, Blaudez D, Brun A (2006) Ammonia: a candidate for nitrogen transfer at the mycorrhizal interface. Trends Plant Sci 11:263-266

Chalot M, Brun A (1998) Physiology of organic nitrogen acquisition by ectomycorrhizal fungi and ectomycorrhizas. FEMS Microb Rev 22:21-44

Chambers SM, Burke RM, Brooka PR, Cairney JWG (1999) Molecular and biochemical evidence for manganese-dependent peroxidase activity in Tylospora fibrillose. Mycol Res 103:1098-1102

Chen DM, Taylor AFS, Burke RM, Cairney JWG (2001) Identification of genes for lignin peroxidases and manganese peroxidases in ectomycorrhizal fungi. New Phytol 152:151-158

Christou M, Avramides EJ, Jones DL (2006) Dissolved organic nitrogen dynamics in a mediterranean vineyard soil. Soil Biol Biochem 38:2265-2277

Courty PE, Pritsch K, Schlotter M, Hartmann A, Garbaye J (2005) Activity profiling of ectomycorrhiza communities in two forest soils using multiple enymatic tests. New Phytol 167:309-319

Ek H (1997) The influence of nitrogen fertilization on the carbon economy of Paxillus involutus in ectomycorrhizal association with Betula pendula. New Phytol 135:133-142 
Ek H, Andersson S, Söderström B (1996) Carbon and nitrogen flow in silver birch and Norway spruce connected by a common mycorrhizal mycelium. Mycorrhiza 6:475-467

Finlay RD, Ek H, Odham G, Söderström B (1988) Mycelial uptake, translocation and assimilation of nitrogen from ${ }^{15} \mathrm{~N}$-labelled ammonium by Pinus sylvestris infected with four different ectomycorrhizal fungi. New Phytol 110:59-66

Finlay RD, Ek H, Odham G, Söderström B (1989) Uptake, translocation and assimilation of nitrogen from ${ }^{15} \mathrm{~N}$-labelled ammonium and nitrate sources by intact ectomycorrhizal systems of Fagus sylvatica infected with Paxillus involutus. New Phytol 113:47-55

Finlay RD, Frostegard A, Sonnerfeldt AM (1992) Utilization of organic and inorganic nitrogensources by ectomycorrhizal fungi in pure culture and in symbiosis with Pinus contorta Dougl Ex Loud. New Phytol 120:105-115

Fischer W-F, André B, Rentsch D, Krolkiezer S, Tegeder M, Britkreuz K, Frommer WB (1998) Amino acid transport in plants. Trends Plant Sci 3:188-195

Frey B, Schüepp (1992) Transfer of symbiotically fixed nitrogen from berseem (Trifolium alexandrinum L.) to maize via vesicular-arbuscular mycorrhizal hyphae. New Phytol 122:447-454

Frey B, Schüepp (1993) Acquisition of nitrogen by external hyphae of arbuscular mycorrhizal fungi associated with Zea mays L. New Phytol 124:221-230

Frey B, Brunner I, Christie P, Wiemken A, Mäder P (1998) The use of polytetrafluoroethylene (PTFE) hydrophobic membrane to study transport of ${ }^{15} \mathrm{~N}$ by mycorrhizal hyphae. In: Varma A (ed) Mycorrhiza manual. Springer, Heidelberg, pp 151-158

Genetet I, Martin F, Stewart GR (1984) Nitrogen assimilation in mycorrhizas - ammonium assimilation in the N-starved ectomycorrhizal fungus Cenococcum graniforme. Plant Physiol 76:395-399

Gessler A, Schneider S, Von Sengbucsh D, Webber P, Hanemann U, Huber C, Rothe A, Kreutzer K, Rennenberg H (1998) Field and laboratory experiments on net uptake of nitrate and ammonium by the roots of spruce (Picea abies) and beech (Fagus sylvatica) trees. New Phytol 138:275-285

Gobert A, Plassard C (2002) Differential $\mathrm{NO}_{3}{ }^{-}$dependent patterns of $\mathrm{NO}_{3}{ }^{-}$uptake in Pinus pinaster, Rhizopogon roseolus and their ectomycorrhizal association. New Phytol 154:509-516

Govindarajulu M, Pfeffer PE, Jin H, Abubaker J, Douds DD, Allen JW, Bucking H, Lammers PJ, Shachar-Hill Y (2005) Nitrogen transfer in the arbuscular mycorrhizal symbiosis. Nature 435:819-823

Grelet GA, Meharg AA, Alexander IJ (2005) Carbon availability affects nitrogen source utilisation by Hymenoscyphus ericae. Mycol Res 109:469-477

Grenon F, Bradley RL, Jones M, Shipley B, Peat H (2005) Soil factors controlling mineral N uptake by Picea engelmanii seedlings: the importance of gross $\mathrm{NH}_{4}^{+}$production rates. New Phytol 165:791-800

Guescini M, Pierleoni R, Palma F, Zeppa S, Vallorani L, Potenza L, Sacconi C, Giomaro G, Stocchi V (2003) Characterization of the Tuber borchii nitrate reductase gene and its role in ectomycorrhizae. Mol Genet Genomics 269:807-816

Guescini M, Zeppa S, Pierleoni R, Sisti D, Stocchi L, Stocchi V (2007) The expression profile of the Tuber borchii nitrite reductase suggests its positive contribution to host plant nitrogen nutrition. Curr Genet 51:31-41

Guidot A, Verner MC, Debaud JC, Marmeisse R (2005) Intraspecific variation in use of different organic nitrogen sources by the ectomycorrhizal fungus Hebeloma cylindrosporum. Mycorrhiza 15:167-177

Haselwandter K, Bobleter O, Read DJ (1990) Degradation of 14C-labelled lignin and dehydropolymer of coniferyl alcohol by ericoid and ectomycorrhizal fungi. Arch Microb 153:352-354

Hawkins H-J, Johansen, George E (1999) Effect of plant nitrogen status on the contribution of arbuscular mycorrhizal hyphae to plant nitrogen uptake. Physiol Plant 105:694-700

Hawkins H-J, Johansen, George E (2000) Uptake and transport of organic and inorganic nitrogen by arbuscular mycorrhizal fungi. Plant Soil 226:275-285

He X, Critchley C, Ng H, Bledsoe C (2004) Reciprocal N $\left({ }^{15} \mathrm{NH}_{4}^{+}\right.$or $\left.{ }^{15} \mathrm{NO}_{3}^{-}\right)$transfer between non- $\mathrm{N}_{2}$-fixing Eucalyptus maculata and $\mathrm{N}_{2}$-fixing Casuarina cunninghamiana linked by the ectomycorrhizal fungus Pisolithus sp. New Phytol 163:629-640 
He X, Critchley C, Ng H, Bledsoe C (2005) Nodulated $\mathrm{N}_{2}$-fixing Casuarina cunninghamiana is the sink for net $\mathrm{N}$ transfer from non- $\mathrm{N}_{2}$-fixing Eucalyptus maculata via an ectomycorrhizal fungus Pisolithus sp. Using ${ }^{15} \mathrm{NH}_{4}^{+}$or ${ }^{15} \mathrm{NO}_{3}^{-}$supplied as ammonium nitrate. New Phytol 176:897-712

Hodge A, Campbell CD, Fitter AH (2001) An arbuscular mycorrhizal fungus accelerates decomposition and acquires nitrogen directly from organic material. Nature 413:297-299

Israel DW (1987) Investigation of the role of phosphorus in symbiotic dinitrogen fixation. Plant Physiol 84:835-840

Jargeat P, Gay G, Debaud JC, Marmeisse R (2000) Transcription of a nitrate reductase gene isolated from the symbiotic basidiomycete fungus Hebeloma cylindrosporum does not require induction by nitrate. Mol Gen Genet 263:948-956

Jargeat P, Rekangalt D, Verner MC, Gay G, Debaud JC, Marmeisse R, Fraissinet-Tachet L (2003) Characterisation and expresion analysis of a nitrate transporter and nitrite reductase genes, two members of a gene cluster for nitrate assimilation from the symbiotic basidiomycete Hebeloma cylindrosporum. Curr Genet 43:199-205

Javelle A, Morel M, Rodriguez-Pastrana BR, Botton B, Andre B, Marini AM, Brun A, Chalot M (2003) Molecular characterization, function and regulation of ammonium transporters (Amt) and ammonium-metabolizing enzymes (GS, NADP-GDH) in the ectomycorrhizal fungus Hebeloma cylindrosporum. Mol Microbiol 47:411-430

Javelle A, Rodriguez-Pastrana BR, Jacob C, Botton B, Brun A, Andre B, Marini AM, Chalot M (2001) Molecular characterization of two ammonium transporters from the ectomycorrhizal fungus Hebeloma cylindrosporum. FEBS Lett 505:393-398

Jentschke G, Brandes B, Kuhn A, Schröder WH, Godbold D (2001) Interdependance of phosphorus, nitrogen, potassium and magnesium translocation by the ectomycorrhizal fungus Paxillus involutus. New Phytol 149:327-337

Jin H, Pfeffer PE, Douds DD, Piotrowski E, Lammers PJ, Shachar-Hill Y (2005). The uptake, metabolism, transport and transfer of nitrogen in an arbuscular mycorrhizal symbiosis. New Phytol 168:687-696

Johansen A, Jakobsen I, Jensen ES (1992) Hyphal transport of ${ }^{15} \mathrm{~N}$-labelled nitrogen by a vesicular-arbsucular mycorrhizal fungus and its effect on depletion of inorganic soil N. New Phytol 122:281-288

Johansen A, Jensen ES (1996) Transfer of N and P from intact or decomposing roots of pea to barley interconnected by an arbuscular mycorrhizal fungus. Soil Biol Biochem 28:73-81

Johansen A, Jakobsen I, Jensen ES (1993) External hyphal of vesicular-arbsucular mycorrhizal fungi associated with Trifolium subterraneum L. 3. Hyphal transport of ${ }^{32} \mathrm{P}$ and ${ }^{15} \mathrm{~N}$. New Phytol 124:61-68

Johansen A, Jakobsen I, Jensen ES (1994) Hyphal N transport by a vesicular-arbsucular mycorrhizal fungus associated with cucumber grown at three nitrogen levels. Plant Soil 160:1-9

Jones DL (1999) Amino acid biodegradation and its potential effects on organic nitrogen capture by plants. Soil Biol Biochem 31:613-622

Jones DL, Hodge A (1999) Biodegradation kinetics and sorption reactions of of three differently charged amino acids in soil and their effects on plant organic nitrogen availability. Soil Biol Biochem 31:1331-1342

Jones DL, Kielland K (2002) Soil amino acid turnover dominates the nitrogen flux in permafrostdominated taiga forest soils. Soil Biol Biochem 34:209-219

Jones DL, Willett VB (2006). Experimental evaluation of methods to quantify dissolved organic nitrogen (DON) and dissolved organic carbon (DOC) in soil. Soil Biol Biochem 38:991-999

Jones DL, Shannon D, Murphy DL, Farrar J (2004) Role of dissolved organic nitrogen (DON) in soil N cycling in grassland soils. Soil Biol Biochem 36:749-756

Jones DL, Healey JR, Willett VB, Farrar JF, Hodge A (2005) Dissolved organic nitrogen uptake by plants-an important $\mathrm{N}$ uptake pathway? Soil Biol Biochem 37:413-423

Kaldorf M, Schmelzer E, Bothe H (1998) Expression of maize and fungal nitrate reductase genes in arbuscular mycorrhiza. Mol Plant Microbe Interact 11:439-448 
Kaye JP, Hart SC (1997) Competition for nitrogen between plants and soil microorganisms. Trends Ecol Evol 12:139-143

Kerley SJ, Read DJ (1997) The biology of mycorrhiza in the Ericaceae XIX. Fungal mycelium as a nitrogen source for the ericoid mycorrhizal fungus Hymenoscyphus ericae (Read) Korf \& Kernan and its host plants. New Phytol 136:691-701

Lambilliotte R, Cooke R, Samson D, Fizames C, Gaymard F, Plassard C, Tatry MV, Berger C, Laudie M, Legeai F, Karsenty E, Delseny M, Zimmermann S, Sentenac H (2004) Large-scale identification of genes in the fungus Hebeloma cylindrosporum paves the way to molecular analyses of ectomycorrhizal symbiosis. New Phytol 164:505-513

Leake JR, Read DJ (1990) Chitin as a nitrogen source for mycorrhizal fungi. Mycol Res 94:993-1008

Lipson D, Näsholm T (2001) The unexpected versatility of plants: organic nitrogen use and availability in terrestrial ecosystems. Oecologia 128:305-316

Lopez-Pedrosa A, Gonzalez-Guerrero M, Valderas A, Azcon-Aguilar C, Ferrol N (2006) GintAMT1 encodes a functional high-affinity ammonium transporter that is expressed in the extraradical mycelium of Glomus intraradices. Fungal Genet Biol 43:102-110

Mäder P, Vierheilig, Streitwolf-Engel R, Boller T, Frey B, Christie P, Wiemken A (2000) Transport of ${ }^{15} \mathrm{~N}$ from a soil compartment separated by a polytetrafluoroethylene membrane to plant roots via the hyphae of arbuscular mycorrhizal fungi. New Phytol 146:155-161

Martin F, Cote R, Canet D (1994) $\mathrm{NH}_{4}^{+}$assimilation in the ectomycorrhizal basidiomycete Laccaria bicolor (Maire) Orton, a ${ }^{15}$ N-NMR study. New Phytol 128:479-485

Melin E, Nilsson H (1952) Transport of labelled nitrogen from an ammonium source to pine seedlings through mycorrhizal mycelium. Svensk Bot Tidskr 46:281-285

Midgley DJ, Chambers SM, Cairney JWG (2004) Inorganic and organic substrates as sources of nitrogen and phosphorus for multiple genotypes of two ericoid mycorrhizal fungal taxa from Woollsia pungens and Leucopogon parviflorus (Ericaceae). Aust J Bot 52:63-71

Montanini B, Moretto N, Soragni E, Percudani R, Ottonello S (2002) A high-affinity ammonium transporter from the mycorrhizal ascomycete Tuber borchii. Fungal Genet Biol 36:22-34

Montanini B, Viscomi AR, Bolchi A, Martin Y, Siverio JM, Balestrini R, Bonfante P, Ottonello S (2006) Functional properties and differential mode of regulation of the nitrate transporter from a plant symbiotic ascomycete. Biochem J 394:125-134

Morel M, Jacob C, Kohler A, Johansson T, Martin F, Chalot M, Brun A (2005) Identification of genes differentially expressed in extraradical mycelium and ectomycorrhizal roots during Paxillus involutus-Betula pendula ectomycorrhizal symbiosis. Appl Environ Microbiol 71:382-391

Morel M, Buee M, Chalot M, Brun A (2006) NADP-dependent glutamate dehydrogenase: a dispensable function in ectomycorrhizal fungi. New Phytol 169:179-190

Müller T, Avolio M, Olivi M, Benjdia M, Rikirsch E, Kasaras A, Fitz M, Chalot M, Wipf D (2007) Nitrogen transport in the ectomycorrhiza association: The Hebeloma cylindrosporum-Pinus pinaster model. Phytochemistry 68:41-51

Nara K (2005) Ectomycorrhizal networks and seedling establishment during early primary succession. New Näsholm T, Persson J (2001) Plant acquisition of organic nitrogen in boreal forests. Physiol Plant 111:419-426

Nehls U, Kleber R, Wiese J, Hampp R (1999) Isolation and characterization of a general amino acid permease Phytol 169:169-178

Näsholm T, Ekblad A, Nordin A, Giesler R, Högberg M, Högberg P (1998) Boreal forest plants take up organic nitrogen. Nature 392:914-916

Nehls U, Kleber R, Wiese J, Hampp R (1999) Isolation and characterization of a general amino acid permease from the ectomycorrhizal fungus: Amanita muscaria. New Phytol 144: 343-349

Persson J, Högberg P, Ekblad A, Högberg MN, Nordgren A, Näsholm T (2003) Nitrogen acquisition from inorganic and organic sources by boreal forest plants in the field. Oecologia $137: 252-257$ 
Plassard C, Bonafos B, Touraine B (2000) Differential effects of mineral and organic N sources, and of ectomycorrhizal infection by Hebeloma cylindrosporum, on growth and $\mathrm{N}$ utilization in Pinus pinaster. Plant Cell Environ 23:1195-1205

Qualls RG, Richardson CJ (2003) Factors controlling concentration, export, and decomposition of dissolved organic nutrients in the Everglades. Biogeochemistry 62:197-229

Quoreshi AM, Ahmad I, Malloch D, Hellebust J (1995) Nitrogen metabolism in the ectomycorrhizal fungus Hebeloma crutuliniforme. New Phytol 131:263-271

Rangel-Castro JI, Danell E, Taylor AF (2002) Use of different nitrogen sources by the edible ectomycorrhizal mushroom Cantharellus cibarius. Mycorrhiza 12:131-137

Read DJ, Perez-Moreno J (2003) Mycorrhizas and nutrient cycling in ecosystems - a journey towards relevance? New Phytol 157:475-492

Reynolds HL, Hartley AE, Vogelsang KM, Bever JD, Schultz PA (2005) Arbuscular mycorrhizal fungi do not enhance nitrogen acquisition and growth of old-field perennials under low nitrogen supply in glasshouse culture. New Phytol 167:869-880

Roberts DM, Tyerman SD (2002) Voltage-dependent cation channels permeable to $\mathrm{NH}_{4}^{+}, \mathrm{K}^{+}$, and $\mathrm{Ca}^{2+}$ in the symbiosome membrane of the model legume Lotus japonicus. Plant Physiol 128:370-378

Rousseau JVD, Sylvia DM, Fox AJ (1994) Contribution of ectomycorrhiza to the potential nutrient-absorbing surface of pine. New Phytol 128:639-644

Scheromm P, Plassard C, Salsac L (1990) Effect of nitrate and ammonium nutrition on the metabolism of the ectomycorrhizal basidiomycete, Hebeloma cylindrosporum Romagn. New Phytol 114:227-234

Selle A, Willmann M, Grunze N, Gessler A, Weiss M, Nehls U (2005) The high-affinity poplar ammonium importer PttAMT1.2 and its role in ectomycorrhizal symbiosis. New Phytol 168:697-706

Smith SE, Read DJ (1997) Mycorrhizal symbiosis, 2nd edn. Academic, San Diego

Sokolovski SG, Meharg AA, Maathuis FJM (2002) Calluna vulgaris root cells show increased capacity for amino acid uptake when colonized with the mycorrhizal fungus Hymenoscyphus ericae. New Phytol 155:525-530

Stribley DP, Read DJ (1980) The biology of mycorrhiza in the Ericaceae VII. The relationship between mycorrhizal infection and the capacity to utilize simple and complex organic nitrogen sources. New Phytol 86:365-371

Tanaka Y, Yano, K (2005) Nitrogen delivery to maize via mycorrhizal hyphae depends on the form of N supplied. Plant Cell Environ 28:1247-1254

Taylor AFS, Martin F, Read DJ (2000) Fungal diversity in ectomycorrhizal communities of Norway spruce (Picea abies (L) Karst) and Beech (Fagus sylvatica L) in forests along northsouth transects in Europe. In: Schulze E-D (ed) Carbon nitrogen cycling in European forest ecosystems. Ecological studies, vol 142. Springer, Heidelberg, pp 343-365

Tibbett M, Sanders FE, Minto SJ, Dowell M, Cairney JWG (1998) Utilization of organic nitrogen by ectomycorrhizal fungi (Hebeloma spp.) of arctic and temperate regions. Mycol Res 102:1525-1532

Tibbett M, Sanders FE, Cairney JWG, Leake JR (1999) Temperature regulation of extracellular proteases in ectomycorrhizal fungi (Hebeloma spp.) grown in axenic culture. Mycol Res 103:707-714

Tobar R, Azcon R, Barea JM (1994) Improved nitrogen uptake and transport from ${ }^{15} \mathrm{~N}$-labelled nitrate by external hyphae of arbuscular mycorrhiza under water-stressed conditions. New Phytol 126:119-122

Toussaint JP, St-Arnaut M, Charest C (2004) Nitrogen transfer and assimilation between the arbuscular mycorrhizal fungus Glomus intraradices Schenck \& Smith and Ri T-DNA roots of Daucus carota L. in an in vitro comparmented system. Can J Microbiol 50:251-260

Turnbull MH, schmidt H, Erskine S, Richards PD, Stewart GR (1996) Root adaptation and nitrogen source acquisition in natural ecosystems. Tree Physiol 16:941-948

Tuskan GA, DiFazio S, Jansson S, Bohlmann J, Grigoriev I, Hellsten U et al. (2006) The genome of black cottonwood, Populus trichocarpa (Torr. \& Gray). Science 313:1596-1604 
Van Aarle IM, Viennois G, Amenc LK, Tatry MV, Luu DT, Plassard C (2007) Fluorescent in situ RT-PCR to visualise the expression of a phosphate transporter gene from an ectomycorrhizal fungus. Mycorrhiza 17:487-494

Vieublé Gonod L, Jones DL, Chenu C (2006) Sorption regulates the fate of the amino acids lysine and leucine in soil aggregates. Eur J Soil Sci 57:320-329

Wallenda T, Read DJ (1999) Kinetics of amino acid uptake by ectomycorrhizal roots. Plant Cell Environ 22:179-187

Warren CR (2006) Potential organic and inorganic N uptake by six Eucalyptus species. Funct Plant Biol 33:653-660

Willmann A, Weiss M, Nehls U (2007) Ectomycorrhiza-mediated repression of the high-affinity ammonium importer gene AmAMT2 in Amanita muscaria. Curr Genet 51:71-78

Wipf D, Bendjia M, Tegeder M, Frommer WB (2002) Characterization of a general amino acid permease from Hebeloma cylindrosporum. FEBS Lett 528:119-124

Wipf D, Bendjia M, Rikirsch E, Zimmermann S, Tegeder M, Frommer WB (2003) An expression cDNA library for suppression cloning in yeast mutants, complementation of a yeast his4 mutant, and EST analysis from the symbiotic basidiomycete Hebeloma cylindrosporum. Genome 46:177-181 